\title{
Going concern modifications and related disclosures in the Italian stock market: do regulatory improvements help investors in capturing financial distress?
}

\author{
Sandro Brunelli ${ }^{1}\left[\right.$ Chiara Carlino ${ }^{1} \cdot$ Rosella Castellano $^{2} \cdot$ Alessandro Giosi $^{3}$
}

Accepted: 12 October 2020 / Published online: 6 November 2020

(c) The Author(s) 2020

\begin{abstract}
This paper investigates the investor reaction to audit reports containing a going concern modification (GCM) in the Italian market following new amendments regarding auditing regulations and public financial information disclosures. We applied the event study (ES) methodology to short event windows considering Italian listed companies during the period 2009-2015. Our findings partially contradict previous studies revealing a systematic negative impact of GCMs, especially when a GCM is attached to unqualified opinions. We clearly observe that Italian auditors have a strong higher propensity to issue a GCM than to express a qualification. Moreover, we find other interesting results that contradict the mainstream literature, detecting a stronger negative reaction in the case of recurring GCMs and when the modification is issued by non-Big 4 auditing firms. These differences could be explained considering the environmental characteristics of the Italian market such as the ownership structure, governance mechanisms and accounting culture, where minority investors act against ownership in accordance with the type II agency problem. Our empirical results suggest that the domestic and international regulatory amendments during the study period have increased the value relevance of GCMs and the usefulness of financial disclosures. This study might be of interest to practitioners and regulators in regard to contributing to the introduction of further regulatory interventions that will enhance both the informativeness of audit reports and awareness of investors in regard to going concern uncertainty.
\end{abstract}

Keywords Going concern modification · Stock market return · Audit report · Italian stock exchange $\cdot$ Governance mechanisms $\cdot$ Audit regulation

Sandro Brunelli

brunelli@economia.uniroma2.it

Extended author information available on the last page of the article 


\section{Introduction}

An audit report is the result of an audit process, and it is considered the auditor's only direct communication with shareholders with regard to the audit process and its outcome (Blay et al. 2011; DeFond and Zhang 2014). Interest in this topic is growing, as demonstrated by the great number of studies in this area, especially the area regarding audit reporting for going concern (GC) uncertainty (Carson et al. 2013; Gold et al. 2019). Among various issues, market reactions to audit opinions represent a historically hot topic and could have consequences not only for current and future shareholders but also for lenders and other capital providers. Over time, investigations of the consequences of going concern modifications (GCMs) for stakeholders have come to constitute an important stream of research (Al-Thuneibat et al. 2008; Brunelli 2018; Carson et al. 2013; Chen and Church 1996; Chen et al. 2000; Chow and Rice 1982; Craswell 1985; Dopuch et al. 1986; Elliott 1982; Firth 1978; Menon and Williams 2010). In this regard, another point that has been investigated at length is investors' market reaction to the GCM release. According to, the literature revealing a negative (or, in a few cases, positive) stock reaction to different types of audit opinions is extensive (Chow and Rice 1982; Dopuch et al. 1986; Ianniello and Galloppo 2015; Menon and Williams 2010; Pucheta-Martínez et al. 2004; Soltani 2000). Undoubtedly, the real effects that a GCM exerts on shareholder behaviour after its issuance are unclear and controversial.

From the international auditing standard setter perspective, the interest in GC culminated in the work of the International Auditing and Assurance Standard Board (IAASB), which, as a part of the "Clarity Project", revised the International Standard on Auditing (ISA) No. 570, on GC, which contained all requirements and procedures that auditors have to implement to verify whether a company has the ability to continue its activity in the foreseeable future. As is well known, when doubts arise over the ability of a company to continue, auditors will consider issuing a GCM. Under the revised ISA 570, when there is material uncertainty regarding the GC assumption but financial statements (FSs) contain adequate disclosures on the issue, a specific paragraph called "Material Uncertainty Related to Going Concern" is attached to the audit opinion. Before this revision, ISA 570 included this GCM section among the plethora of other issues in the so-called "emphasis of matter paragraphs".

With the aim of entering and expanding the debate, our study focuses on the market response to audit reports containing a GCM for Italian listed firms, excluding banks and insurance companies, in the period 2009-2015. We specifically examine the effects of different types of audit opinions containing GCMs on investors, as reflected in abnormal stock returns. We adopt the event study (ES) methodology and use a battery of statistical tests. Due to the peculiarity of the Italian market, where regulations require separate announcements for each type of relevant information, we investigate only GCMs without considering other potential types of information released (e.g., earnings announcements or earnings forecasts).

The results show that investors have a strong negative reaction to GCMs especially in the days around and after the event date; surprisingly, however, the 
impact is mostly detected for unqualified opinions containing GCMs. Ianniello and Galloppo (2015) studied the Italian stock market considering a shorter period (2007-2010). Different from our results, they detected negative effects on stock prices only for GCMs attached to qualified opinions (except for, disclaimer and adverse opinions) but a positive reaction to unqualified opinions with GCMs. Notably, since 2009, due to the deterioration of the macro-economic situation, Italian regulators have included a GCM attached to an unqualified opinion among the "relevant information for investors", subject to an immediate communication to the stock market. This aspect could make the time span adopted by Ianniello and Galloppo unsuitable for detecting the investor reaction. According to our findings, the regulatory amendment noted above represents the primary reason for the negative cumulative abnormal returns of stock prices around the information release (event date) and for the increased investor sensitivity to unqualified GCMs. Our findings represent an additional positive answer to the question of whether new disclosure requirements produce benefits for minority shareholders (Allegrini and Greco 2013).

Connecting theory with empirical evidence, this study shows how Italy is an interesting context in which minority investors know that they have weak protections and, for this reason, take GCMs issued by non-Big 4 auditors more into consideration, as revealed when splitting the analysis between Big-4 and non-Big 4 auditors. Moreover, we detect that negative reactions are not simply due to the audit opinion type and/or modification; rather, they are attributed to the joint reading of both audit opinions and firms' financial highlights. Conducting additional tests, this study also finds that recurring GCMs have a higher negative impact on investors, a result that is the opposite of that of the mainstream literature (Blay and Geiger 2001; Blay et al. 2016; Geiger and Kumas 2018; Herbohn et al. 2007; Kaplan et al. 2014; Menon and Williams 2010), which assigns this role to first GCMs. Finally, we also show how GCMs released for the FSs of blacklisted companies determine a more severe adverse reaction among investors.

The time span encompassed in our empirical investigation (2009-2015) has its own intrinsic validity in isolating the investor reaction to GCMs in a period characterized by financial crisis (Achim et al. 2010), domestic regulatory amendments (2009-2010) and the international regulatory amendment process (2012-2015). We stopped the analysis at 2015 in light of the revised version of ISA 570 for FSs ending on 15 December 2016 that entered into force, changing and extending the content of the GC paragraph in audit reports. Thus, from the regulatory perspective, the sample analysed is homogeneous.

This study contributes to the literature in a unique legal setting that has been underexplored by the existing literature, and it provides a more complete picture of Italian investors' reactions to GCMs. Future studies may replicate the methodology adopted to test further changes in the investor reaction to auditor GC remarks in the period after the financial crisis and in light of further modifications to the audit regulatory environment.

Moreover, compared to the methodology adopted in previous studies, our work represents an advance since in the calculation of abnormal returns, we adopt a weighted stock index generated considering the firms included in the sample under 
investigation plus a matching sample of healthy firms operating in the same sectors. We replaced the FTSE MIB (the main Italian stock index) to better represent companies included in the sample under investigation. Indeed, the FTSE MIB includes only the top 40 Italian listed companies in terms of market capitalization, floating shares and liquidity. Thus, the use of FTSE MIB may result in misleading interpretations if abnormal returns are calculated by departing from it. As shown in a separate appendix, the use of this ad hoc built index allows us to improve the accuracy of both our findings and our interpretation of the results.

The remainder of the paper proceeds as follows. Section 2 describes the institutional setting of auditing in Italy and its development over time with respect to the GC issue. Section 3 discusses prior studies in the field and builds hypotheses. Section 4 presents the sample data and the methodologies used for the empirical analysis. Section 5 outlines the main findings and results. Section 6 provides a critical discussion of the results achieved. Section 7 concludes with final remarks, study limitations and trajectories for further research.

\section{The legislative setting of auditing in Italy}

Italy started to regulate the auditing environment in 1974. For the purpose of our study, it seems useful to depict domestic and international regulatory changes and amendments from 2006 onward, when the auditing internationalization process began. However, the main changes brought since the inception of Italian auditing regulation are depicted in Table 1.

With Directive No. 2006/43/EC, the European Parliament established that the audit process is obligated to follow ISAs. Consequently, Legislative Decree No. $32 / 2007$ updated the audit report structure and aligned it with the international trends in auditing, but it did not implement EU directive 2006/43.

During the period 2004-2009, the IAASB rewrote many ISAs, which were named "clarified" ISAs, with the aim of overcoming some incompatibilities between standards and the legislations of several EU countries. Ultimately, the European Directive of 2006 was transposed in Italy with articles 11 and 12 of Legislative Decree No. $39 / 2010$, establishing that an "audit is to be conducted in accordance with ISAs". In any case, the "clarified" ISAs (including ISA 570 on "going concern") were adopted in Italy only in 2014 with "Determina" No. 100736 of the General Accounting Office (an operational arm of the Ministry of Finance).

Looking at the accounting regulations, as required by IAS 1, managers have to include in the annual report an assessment of an entity's ability to continue as a GC. This requirement has an impact on audit procedures because if some doubts on the GC basis arise, auditors are required to conduct further investigation to verify the issues and to provide additional information in the audit report. This evaluation has been required in Italy since audit reporting practices were first implemented. To emphasize the growing relevance of this matter, European Regulation No. 2014/537/ EU provides that auditors have the duty to promptly report to competent authorities any significant fact or doubts about a company's GC assumption. In Italy, this "early warning" has been required since 2009. Indeed, CONSOB Communication 
Table 1 Regulatory events and changes in the auditing Italian legislative settings

Date Event

Before the investigation period

June 6, 1974

March 31, 1975

April 8, 1982

1987, 1994

February 28, 1998 (revised in 2007)

December 1, 1999

January 17, 2003

2004

May 17, 2006 (revised in 2014)

February 2, 2007

Period examined in the study

October 2007 (revised in 2014 and in 2015)

2009

September 16, 2009
Law No. 216

Establishment of the CONSOB

Introduction of the audit "certification" for listed companies

Presidential Decree No. 136

Implementation of Law No. 216/1974

CONSOB Resolution No. 1079

Recommendation of "Audit Document" No. 1-21

CONSOB's Communications No. 87/02794 and 94/001751

First prevision to graduate the degree of opinions; first introduction of the "emphasis of matter paragraph"

Legislative Decree No. 58 "Consolidated Law of Finance"

Separation between the supervisory authority ("internal statutory board of controllers") and audit committee; implementation of the four degrees of opinions; definition of the structure of the audit "report"

CONSOB Communication No. DAC/99088450 Implementation of Legislative Decree No. 156/1998

Legislative Decree No. 6 "Company Law Reform"

Reform of companies; changes in the tasks of auditors and the internal statutory board of controllers

Start of the revision process of the International Standards on Auditing, named the "clarify project"

European Directive 2006/43/EC

Full revision of audit activities in the European Union; request statutory auditors and audit firms to carry out statutory audits in compliance with international auditing standards (ISAs) or national auditing standards as long as the commission has not adopted an ISA covering the same subject matter

Legislative Decree No. 32, which transposes European Directive 2003/51/EC

Modification to Legislative Decree No. 58/98 and art. 2409-ter Civil Code in regard to the structure of the audit report

CNDCEC released "Document 570", named "Going Concern", replacing Document No. 21 (after substituted by ISA "Italia" 570 and by ISA "Revised" 570)

End of the revision process of the "clarified" ISA

CONSOB Communication No. DME/9081707

Inclusion of unqualified opinions with a GCM in the relevant information to be immediately communicated to the market 
Table 1 (continued)

\begin{tabular}{|c|c|}
\hline Date & Event \\
\hline January 27, 2010 (revised in 2014 and 2015) & $\begin{array}{l}\text { Legislative Decree No. } 39 \text { "Consolidated Law on Statu- } \\
\text { tory Audits" } \\
\text { Implementation of Directive } 2006 / 43 / \mathrm{EC} \text { and collection } \\
\text { in one document of all audit rules. }\end{array}$ \\
\hline December 23, 2014 & $\begin{array}{l}\text { "Determina" of the General Accountant Office No. } \\
100736 \\
\text { Implementation of the "clarified" ISA (also named ISA } \\
\text { "Italia") in Italy (in force since January 1, 2015) }\end{array}$ \\
\hline \multicolumn{2}{|l|}{ After the investigation period } \\
\hline April 16, 2014 (effective from June 17, 2016) & $\begin{array}{l}\text { European Directive } 2014 / 56 / \mathrm{EU} \\
\text { Introduction in the audit report of a statement on any } \\
\text { material uncertainty related to events or conditions } \\
\text { that may cast significant doubt on the entity's ability } \\
\text { to continue as a GC }\end{array}$ \\
\hline $\begin{array}{l}\text { January } 2015 \text { (effective for audits of FSs for } \\
\text { periods ending on or after December 15, } \\
\text { 2016) }\end{array}$ & $\begin{array}{l}\text { Issuance of the new ISA } 260 \text { (Revised), Communica- } \\
\text { tion with Those Charged with Governance; ISA } \\
570 \text { (Revised), Going Concern; ISA } 700 \text { (Revised) } \\
\text { Forming an Opinion and Reporting on Financial } \\
\text { Statements; New ISA 701, communicating Key Audit } \\
\text { Matters in the Independent Auditor's Report; ISA } \\
705 \text { (Revised), Modifications to the Opinion in the } \\
\text { Independent Auditor's Report; ISA } 706 \text { (Revised), } \\
\text { Emphasis of Matter Paragraphs and Other Matter } \\
\text { Paragraphs in the Independent Auditor's Report } \\
\text { The section addressing doubts on the GC assumption is } \\
\text { called "material uncertainty related to going concern" } \\
\text { (ISA } 570 \text { "Revised) }\end{array}$ \\
\hline
\end{tabular}

No. DME/9081707 has included an unqualified opinion with a GCM in the relevant information to be immediately communicated to the market. Prior to 2009, auditors were obligated to broadcast only qualified opinions to CONSOB and to the market. Thus, Italy has anticipated the orientation of the European Union in regard to the immediate market disclosure of every GCM. In light of this setting, we expect to find a high sensitivity of investors to the release of unqualified opinions with GCMs, a sensitivity that, to date, has never been empirically detected.

The most important regulatory changes reviewed are summarized in Table 1.

The extent of these regulatory changes provides a strong motivation to examine more in depth and for a longer period the impact of GC modified audit opinions on the stock market in Italy.

As is well known, audit opinions can be classified into two groups:

1. Unmodified (also called unqualified) opinions and

2. Qualified and modified opinions.

For our purposes, it is possible to further classify group 1 into:

1a. clean opinions, 


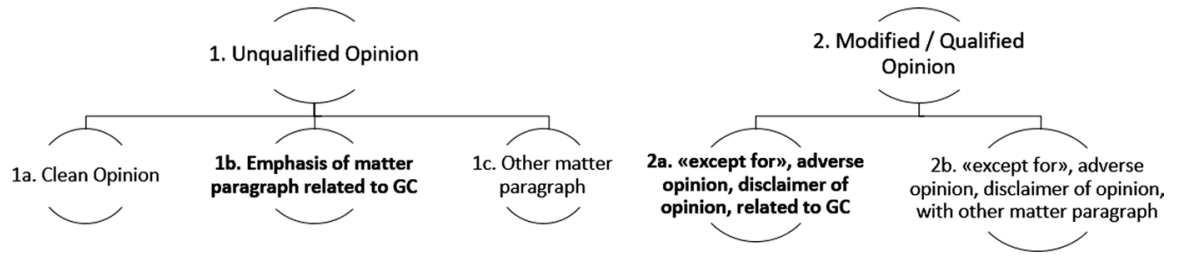

Fig. 1 Audit opinions categorization for the empirical analysis. Audit opinions categorization adopted by the ISA's, focusing in particular on GC (Going Concern). In the study the attention was focused on subgroups $1 \mathrm{~b}$ and $2 \mathrm{a}$

1b. clean opinions with an emphasis of matter paragraph related to GC (also called an unqualified opinion with a GCM), and

1c. clean opinions with other matter paragraphs.

At the same time, we can distinguish group 2 into:

2a. those qualified (in the form of "except for", adverse opinions and disclaimer of opinion) with a GCM and

2b. those qualified (in the form of "except for", adverse opinions and disclaimer of opinion) with no or other matter paragraphs (modifications).

In this paper, we primarily focus on subgroups $1 \mathrm{~b}$ and $2 \mathrm{a}$, as shown in Fig. 1.

In addition to Italian audit regulations and their recent upgrades, it is important to review the chronological order followed by Italian listed firms in disseminating their financial reporting information during the process of FSs approval. This review aims to understand whether the audit report date per se can be considered an event having the potential to generate stock market abnormal returns.

The Company Law Reform of 2003, regarding the procedure for FSs approval for partnerships and corporations, established that (art. 2364 of the Italian Civil Code) companies have 120 days (or 180 days for the extended term) after the end of the fiscal year for FSs approval. FSs approval proceeds as follows: after approving the draft FSs, the board of directors must convene at the ordinary shareholders' meeting. Under art. 154-ter of the Consolidated Law of Finance, the board of directors must convey the draft FSs to the internal statutory board of auditors and to the external auditor at least 15 days before disclosing them to the market (art. 66 of the Issuers' Regulation). Between the public dissemination of the draft FSs (yearly earnings announcement) and the date of the ordinary shareholders' meeting, there must be a gap of at least 21 days. In contrast, the auditor must issue the audit report and file it with the company's registered office at least 15 days before the date of the ordinary shareholders' meeting (art. 2429 Civil Code and art. 154-ter Testo Unico della Finanza-TUF). The law does not provide a precise length of time for auditors to carry out audit procedures and issue their audit opinion. However, from the description above, it can be concluded that in cases where the board of directors releases the draft FSs exactly 15 days before the official yearly earnings announcement, auditors have a maximum of 21 days to complete their work. When the yearly earnings announcement is provided, the draft FSs 


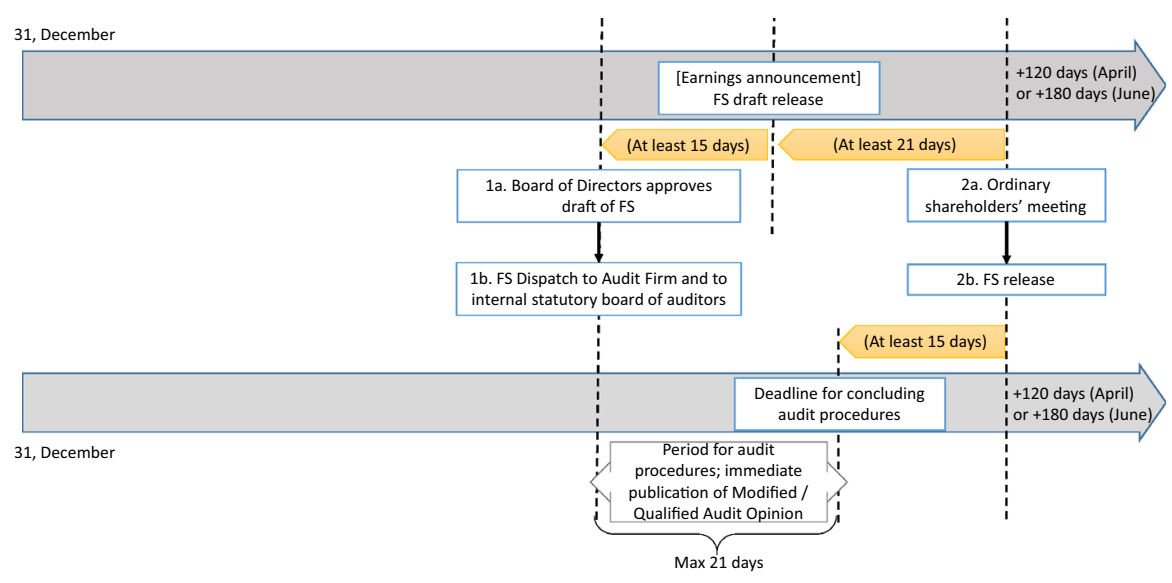

Fig. 2 Mechanism for the disclosure of financial reporting information during the process of approval of FS. Mechanism adopted for the disclosure of the FS (Financial Statements) and the audit report during the process of approval of FS

is revealed through press releases, publication on the company's web site and communication to CONSOB. It is important to clarify that press releases of the draft FSs do not contain any reference to the audit report and vice versa. The aforementioned inclusion of a GCM among the relevant information for investors that occurred in 2009 implies that in the very instant when the auditor releases a GCM, the stock market must immediately receive a specific press release, and the audit report must be immediately disclosed. Such communication is not required in the case of a clean opinion or an unqualified opinion containing other emphasis of matter paragraphs. The effects of this provision are evident: in the case of GC modified audit reports, investors can read the audit report earlier than 15 days before the complete FSs is released. On the other hand, in the case of a clean opinion or a clean opinion containing emphasis of matter paragraphs other than GC, investors can read the audit report only during the 15 days before the ordinary shareholders' meeting, by going directly to the company's legal headquarters or, later, by reading the official annual report. Thus, a potential greater impact of the release of a GCM on the stock market is expected. Finally, the regulatory improvement of 2009 facilitates the separation between the release of GCMs and other relevant financial disclosures. The procedures for FSs approval and those related to the disclosure of relevant information set out above are shown in Fig. 2 and, after this review, it seems clear how the GC modified audit report date should be considered an event that is able to determine abnormal stock market returns, warranting further investigation.

\section{Audit report releases and stock market reactions: literature review and hypothesis development}

The informativeness and usefulness of audit reports have been investigated at length in the literature (Foster et al. 1998). As shown in previous research (Blay et al. 2011; DeFond and Francis 2005), the audit opinion is the only existing 
tool available to auditors for communicating with stakeholders. Especially in the past, the focus was on the impacts of qualified audit opinions, without separately distinguishing GCMs (Alderman 1977; Baskin 1972; Davis 1982; Dopuch et al. 1986). All these studies were conducted in the U.S., where pioneers such as Baskin (1972) and Davis (1982) found no information content for "consistency exceptions" or "subject-to" audit opinions, respectively. On the other hand, Alderman (1977) and Dopuch et al. (1986) found evidence of the informational value of uncertainty qualifications.

Later, considering the growing relevance of this topic, many researchers investigated the consequences of GCMs. In particular, Carson et al. (2013), in their seminal work of research synthesis on audit reporting for GC uncertainty, discussed the impact of GCMs on investors, stressing that market reactions to audit reports could have consequences not only for current and future shareholders but also for lenders and other capital providers. Some studies addressed the issue of changes in the cost of equity capital after a GCM. Amin et al. (2014) and Chen et al. (2016) found a positive association between GCMs and the cost of capital, both equity and debt, suggesting that investors and lenders use this information to protect their interests by demanding a greater risk premium (Karjalainen 2011).

With respect to GCM effects on lenders, LaSalle and Anandarajan (1996) found that a GCM reduces loan officers' willingness to grant a line of credit and decreases the assessment of company creditworthiness. This result is in contrast with that of Bessell et al. (2003), who found a significant effect of GCMs on risk perception or on decisions related an entity's ability to respect the line of credit.

Regardless, the majority of research mainly focuses on the market reaction to audit opinions, observing the effects on current or future shareholders and on different dates. These studies do not achieve univocal results (Brunelli 2018). In fact, a negative return could be registered during the days after a GCM, as demonstrated by Menon and Williams (2010) for the U.S., by Citron et al. (2008) for the U.K., and by Hsu et al. (2011) for Taiwan. In particular, Menon and Williams (2010), considering various types of information included in a GCM, showed that the reaction is more negative if the audit report cites problems related to obtaining financing. This implication is relevant since it highlights that investors also take into account the content of the audit opinion and the severity of the reasons for it (Geiger and Kumas 2018).

On the other hand, the effect on stock prices could be null or positive: PuchetaMartínez et al. (2004), considering the Spanish stock market, did not find a significant impact of GCMs.

As noted by Mock et al. (2013) in their research synthesis on the audit report, "studies generally reveal that the market reacts to the issuance of reports other than standard unqualified reports". Therefore, considering the characteristics of the Italian market and consistent with the results of Ianniello and Galloppo (2015), we expect that qualified and unqualified opinions containing GCMs have an impact on stock prices. Under these considerations, with the aim of extending previous Italian results, analysing a larger sample, more years and drawing a more comprehensive picture of the topic, we formulate our first hypothesis: 
H1 Reports containing qualified audit GC modified opinions or unqualified audit GC modified opinions have a significant negative effect on share prices, as revealed by abnormal returns for the common stock of firms.

In examining this issue, a problem that arises is the sufficiency of different types of GC modified audit opinions in determining significant abnormal returns. In the past, Gray et al. (2011) and Porter et al. (2009) showed that a large proportion of FSs users or nonprofessional investors never or rarely read the audit report; that is, they focused their attention only on the type of opinion (whether qualified or unqualified). However, Pei and Hammill (2013) suggested that both unqualified opinions with explanatory notes and qualified opinions have negative information content to various degrees for the market.

Moreover, as mentioned above, Menon and Williams (2010) found that investors observe the content of the audit report and the severity of the words used in the modification (Geiger and Kumas 2018). Following this orientation, a recent study conducted by Czerney et al. (2019) investigated whether investors respond to the explanatory language (EL) added to unqualified audit reports. They did not find a general answer with regard to EL at the time of the audit report release, especially due to previous knowledge of the information and a poor understanding of the relevance of the audit report. However, separately analysing different categories of EL, they hypothesized and found that investors respond negatively to a GCM with EL. They concluded that both regulators and policymakers should strive to improve the usefulness and the information content of the audit report. Thus, following these considerations, we state our second hypothesis as follows:

H2 Unqualified audit opinions with GCMs have a negative impact on share prices, as revealed by abnormal returns for the common stock of firms.

In addition to the reasons above, it is important to underline that our expectation regarding unqualified GC modified opinions is the opposite of the result obtained by Ianniello and Galloppo (2015). In fact, we consider a longer period in which, as mentioned above, since 2009 , the relevance of unqualified opinions with GCMs must be immediately communicated to the market, as well as other types of modified or qualified opinions. At the same time, unlike Czerney et al. (2019), we did not test the investor reaction to unqualified opinions with matter paragraphs other than GC since the Italian regulatory setting does not consider them to be relevant information for the market requiring an immediate, specific and separate disclosure.

Since the pioneering studies on this topic, researchers have focused on unexpected (first-time) GCMs (Fleak and Wilson 1994; Jones 1996; Loudder et al. 1992). Recently, Mock et al. (2013) have reinforced this orientation, finding that "unless 'new' information is provided, a GC modified audit report does not appear to have significant information content". For this reason, many authors (Blay and Geiger 2001; Blay et al. 2016; Geiger and Kumas 2018; Herbohn et al. 2007; Kaplan et al. 2014; Menon and Williams 2010) test investors' reaction only to first-time GCMs. The results of these studies generally show a negative reaction to first-time GCMs, 
with the exception of Herbohn et al. (2007), who found that first-time GCMs lead to a significant adverse market reaction prior to the event date; however, they did not find evidence of a persistent reaction after the announcement. Conversely, Amin et al. (2014) analysed the different contributions of first-time GCMs and recurring GCMs, showing that GCMs are associated with firms' subsequent cost of equity, but in the case of first-time GCMs, the coefficient of significance is higher. Considering that in Italy this aspect has never been explored, it is interesting to split the sample and separately observe the investor reaction to first-time and recurring (two or more times) GCMs. Following the general trend of previous studies, we expect that a firsttime GCM generates a higher negative impact on stock prices compared to recurring GCMs. Hence, the third hypothesis is as follows:

H3 First-time GCMs have a higher negative effect on stock prices than recurring GCMs, as revealed by abnormal returns.

\section{Research design and methodology}

\subsection{Data sample description}

We analysed audit reports of separate and consolidated FSs, but we included only observations extrapolated from consolidated annual reports and separate FSs when the consolidated account was not available. The dataset used for the analysis was gathered from different sources: stock market prices and financial data were retrieved from Thomson Reuters Datastream, while audit reports were collected by downloading firms' annual reports from their official websites. The period covered is from 2009 to 2015 (fiscal years). The sample selection started by considering any new listed or delisted firm in the period under investigation. In this way, all listed companies, even those listed only 1 year during the time span, were included in the sample.

Starting from a potential sample of 2049 firms/observations, we decided to exclude banks and insurance companies to be aligned with the literature, particularly with the only extant study located in Italy (Ianniello and Galloppo 2015). Moreover, even if we recognize the similarity of audit reports among different industries and sectors, the FSs and related ratios are different in terms of both the formulas and the drivers that may one outperforming another.

Then, we removed companies with missing opinions. In this way, the total sample dropped to 1540 firms/observations.

To classify audit opinions, we used the categorization established by ISA 700, on forming an opinion and reporting on FSs. Preliminarily, we separated those containing a GCM from those not containing a GCM. The majority of them $(n=1282$, $83.2 \%$ ) did not receive a GCM. Hence, only 258 observations (16.8\%) contained a GCM. Among them, we found firms for which some data were missing (such as unreliable stock market data). Ultimately, the total clean sub-sample that we consider in our analysis was composed of 235 observations from 68 unique firms. Among them, 71 observations contained qualifications ("except for", adverse opinions and 
disclaimer of opinion), representing 30.2\% of GCMs. The remaining 164 (68.8\%) observations refer to unqualified opinions with GCMs. The breakdown of the sample, by year and by type of audit opinion, is provided in Table 2.

Observing the composition of the sample, we can preliminarily conclude that auditors, when financial troubles are incoming or expected in the next future, prefer to issue a disclaimer rather than an adverse opinion. Indeed, the latter can hardly be considered unfavourable, at least for minority shareholders.

Panel A of Table 3 provides the descriptive statistics of the sample of GCMs, showing FSs items and ratios mainly related to GC, in accordance with, among others, Carson et al. (2013) and Taffler et al. (2004).

Not surprisingly, the firms in the sample, which, by definition, are in financial distress, have a low or medium market capitalization (mean SIZE $=55.5$ million) and a negative net income (mean $\mathrm{NI}=-27.5$ million $€$ ). The sample presents high variability in terms of leverage and total assets. In line with the definition of financial distress, it is worth highlighting the average negative return on assets (mean $\mathrm{ROA}=-12.5 \%$ ) and the average high leverage (mean LEV $=-422.6 \%$ ) of the sample firms.

Panel B provides some information referring to the subsample of unqualified opinions with GCMs. In contrast to expectations, these firms present financial ratios that are not much better than those of Panel A, showing a situation of generalized financial distress.

Panel C presents additional information on the sample and subsample, showing that a great percentage of firms registered a net loss, the majority of the total sample had a current ratio $<1$, approximately $50 \%$ of the total sample registered a net loss higher than the net equity and, finally, $27 \%$ of the total sample firms had negative equity. Additionally, in Panel $\mathrm{C}$, there is unexpected evidence of financial distress for companies with unqualified opinions with GCMs.

Aiming to test our hypotheses, we sorted an equal number of observations for not financially distressed companies, which did not receive qualified or modified audit opinions during the investigated period. To be included in this matched sample a firm must own, contemporarily, the following characteristics: (1) listed at the Milan Stock Exchange in the same years of a correspondent firm in the main sample; (2) belonging to the same or similar sectors of a firm in the main sample; (3) displays a similar size (in terms of total assets) of a firm in the main sample; 4 not to be a bank or an insurance company. The matching process was carried out on a one-to-one basis, obtaining 68 firms matched to the 68 firms in the main sample. Finally, the event dates of the 235 observations in the main sample have been assigned to the matched sample respecting the oneto-one matching. ${ }^{1}$ This process led us to get 235 observations for each sample.

\footnotetext{
1 The event date allocation from the main sample to the matched sample is only used to calculate the weighted market index. Indeed, the procedure for its calculation establish to consider the market capitalization, the number of shares outstanding and the stock price of each firm included in the sample under investigation in a specific day. The only way to have a date for the matched sample, is to use the event dates of the GCM firms, due to the lack of the GCM release for the matched sample.
} 


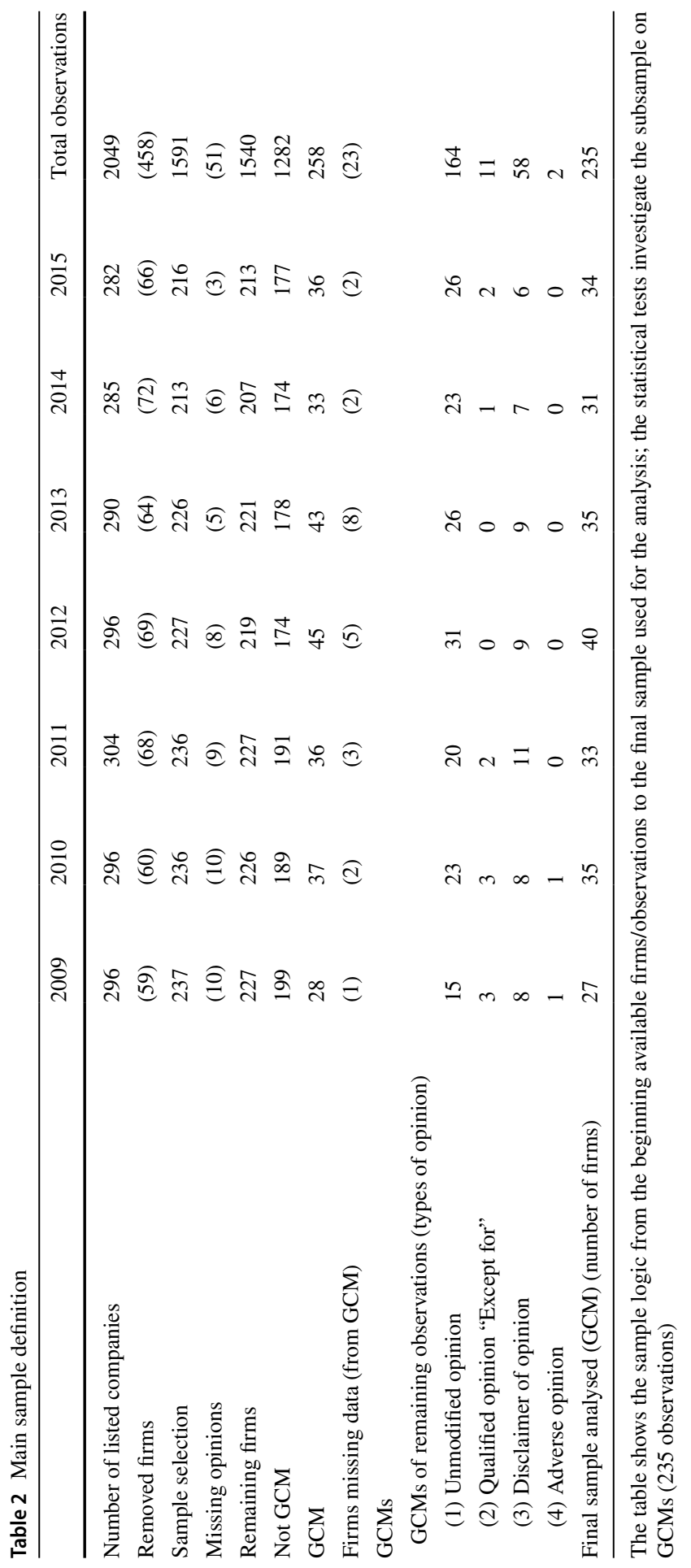


Table 3 Descriptive statistics of the main sample

\begin{tabular}{|c|c|c|c|c|c|}
\hline Variable $^{\mathrm{a}}$ & Mean & Std. dev. & Median & Minimum & Maximum \\
\hline \multicolumn{6}{|c|}{ Panel A—full GCM sample $(n=235)$ —main ratios } \\
\hline TA (million euros) & 255.92 & 434.57 & 131.74 & 0.58 & 3753.92 \\
\hline SIZE (million euros) & 55.46 & 96.46 & 26.44 & 1.40 & 935.64 \\
\hline NI (million euros) & -27.48 & 77.62 & -12.95 & -794.24 & 205.25 \\
\hline EQ (million euros) & 19.62 & 80.05 & 9.57 & -568.76 & 357.84 \\
\hline Net sales (million euros) & 148.64 & 283.98 & 67.14 & 0.00 & 2135.28 \\
\hline $\mathrm{ROA}(\%)$ & -12.51 & 21.12 & -6.00 & -191.07 & 22.56 \\
\hline $\operatorname{LEV}(\%)$ & 422.64 & 2068.53 & 113.88 & -7767.84 & $20,526.84$ \\
\hline Current ratio & 1.43 & 6.16 & 0.72 & 0.08 & 79.61 \\
\hline \multicolumn{6}{|c|}{ Panel B-unqualified opinion with GCMs subsample $(n=164)$-main ratios } \\
\hline TA (million euros) & 302.90 & 505.74 & 143.10 & 0.58 & 3753.92 \\
\hline SIZE (million euros) & 69.53 & 111.24 & 32.89 & 2.14 & 935.64 \\
\hline NI (million euros) & -29.94 & 91.50 & -10.29 & -794.24 & 205.25 \\
\hline EQ (million euros) & 27.65 & 91.78 & 15.33 & -568.76 & 357.84 \\
\hline Net sales (million euros) & 162.08 & 321.31 & 68.31 & 0.00 & 2135.28 \\
\hline ROA (\%) & -11.10 & 22.05 & -5.01 & -191.07 & 22.56 \\
\hline $\operatorname{LEV}(\%)$ & 440.24 & 1741.26 & 157.89 & -7767.84 & $14,372.06$ \\
\hline Current ratio & 1.78 & 7.22 & 0.78 & 0.09 & 79.61 \\
\hline \multirow[t]{2}{*}{ Variable $^{\mathrm{b}}$} & \multicolumn{2}{|c|}{ All GCMs $(n=235)$} & \multicolumn{2}{|c|}{$\begin{array}{l}\text { Unqualified opinions with } \\
\text { GCMs }(n=164)\end{array}$} & \\
\hline & Number & $\%$ of sample & Number & $\%$ of sub-sample & \\
\hline \multicolumn{6}{|l|}{ Panel $\mathrm{C}$-other variables } \\
\hline LOSS & 205 & 87.23 & 140 & 59.57 & \\
\hline Equity $<0$ & 63 & 26.81 & 31 & 13.19 & \\
\hline LOSS $>$ equity & 116 & 49.36 & 64 & 27.23 & \\
\hline
\end{tabular}

Panel A presents the summary statistics related to our population of 235 firms/observations from 68 unique companies listed on the Italian Stock Exchange receiving a GCM between January 1, 2009, and December 31, 2015. Panel B presents the same summary statistics related to the sub-sample of firms/ observations receiving an unqualified opinion with a GCM in the same period. Panel $\mathrm{C}$ reports the results of other firms in the observed period between the population and the subsample of unqualified opinions with GCMs

${ }^{a}$ Variable definitions: TA, total assets in $€$ million; SIZE, market capitalization in $€$ million; NI, net income in $€$ million; EQ, equity in $€$ million; Net Sales, sales in $€$ million; ROA, return on assets (net income/average total assets) in percentage; LEV, leverage (debt/common equity) in percentage; Current ratio (current assets/current liabilities). The data for compiling the descriptive statistics were gathered from Datastream

${ }^{b}$ Variable definitions: LOSS, number of firms registering a loss; Equity $<0$, number of firms registering equity less than 0; LOSS $>$ Equity, number of firms registering a loss higher than equity; Current Ratio $<1$, number of firms registering a current ratio less than 1

This matched sample was exclusively used to build a new weighted stock market index instead of the main Italian stock index (FTSE MIB). We expand upon this issue in the following sections. The descriptive statistics of the matched sample 
Table 4 Descriptive statistics - matched sample

\begin{tabular}{lrrrrr}
\hline Panel A-main ratios- $(\mathrm{n}=235)$ & & & & \\
\hline Variable $^{\mathrm{a}}$ & \multicolumn{1}{l}{ Mean } & Std. dev. & Median & Minimum & Maximum \\
\hline TA (million euros) & 293.97 & 449.06 & 114.63 & 3.43 & 3748.02 \\
SIZE (million euros) & 140.11 & 304.60 & 36.86 & 1.38 & 2628.48 \\
NI (million euros) & 1.41 & 20.49 & 0.13 & -79.21 & 155.75 \\
EQ (million euros) & 118.08 & 169.87 & 54.82 & -26.84 & 763.96 \\
Net sales (million euros) & 194.34 & 393.54 & 76.05 & 0.49 & 3011.64 \\
ROA (\%) & 1.07 & 5.87 & 1.31 & -18.99 & 31.05 \\
LEV (\%) & 112.66 & 147.50 & 70.01 & -70.97 & 965.95 \\
Current ratio & 2.79 & 7.49 & 1.39 & 0.19 & 65.71 \\
\hline
\end{tabular}

Panel B-other variables

\begin{tabular}{lcc}
\hline Variable $^{\mathrm{b}}$ & \multicolumn{2}{l}{ Matched sample $(\mathrm{n}=235)$} \\
\cline { 2 - 3 } & Number & $\%$ of sample \\
\hline LOSS & 113 & 48.09 \\
Equity $<0$ & 2 & 0.85 \\
LOSS $>$ equity & 24 & 10.21 \\
Current ratio $<1$ & 55 & 23.40 \\
\hline
\end{tabular}

a Variable definitions: TA, total assets in $€$ million; SIZE, market capitalization in $€$ million; NI, net income in $€$ million; EQ, equity in $€$ million; Net Sales, sales in $€$ million; ROA, return on assets (net income/average total assets) in percentage; LEV, leverage (debt/common equity) in percentage; Current ratio (current assets/current liabilities). The data for compiling the descriptive statistics were gathered from Datastream

${ }^{b}$ Variable definitions: LOSS, number of firms registering a loss; Equity $<0$, number of firms registering equity less than 0; LOSS $>$ Equity, number of firms registering a loss higher than equity; Current Ratio $<1$, number of firms registering a current ratio less than 1

are provided in Table 4. Firms included in the both main sample and matched sample, as well as the event dates are reported in Appendix 1.

Comparing the firms within the two samples (main sample vs. matched sample), it is possible to see that although they have similar total assets, their performance is completely different. The matched firms have an average positive income (mean $\mathrm{NI}=1.41$ million $€$ ), positive return on assets (mean $\mathrm{ROA}=1.07 \%$ ) and a higher current ratio (mean $=2.79)$. Moreover, the control firms are larger in terms of market capitalization (mean SIZE $=140.11$ million $€$ ) and equity (mean $\mathrm{EQ}=118.08$ million $€$ ). Finally, a lower number of them have a current ratio $<1$ ( $23 \%$ of the matched sample) and registered a loss in the period under investigation (approximately 50\%), with only two cases of losses being higher than equity. 


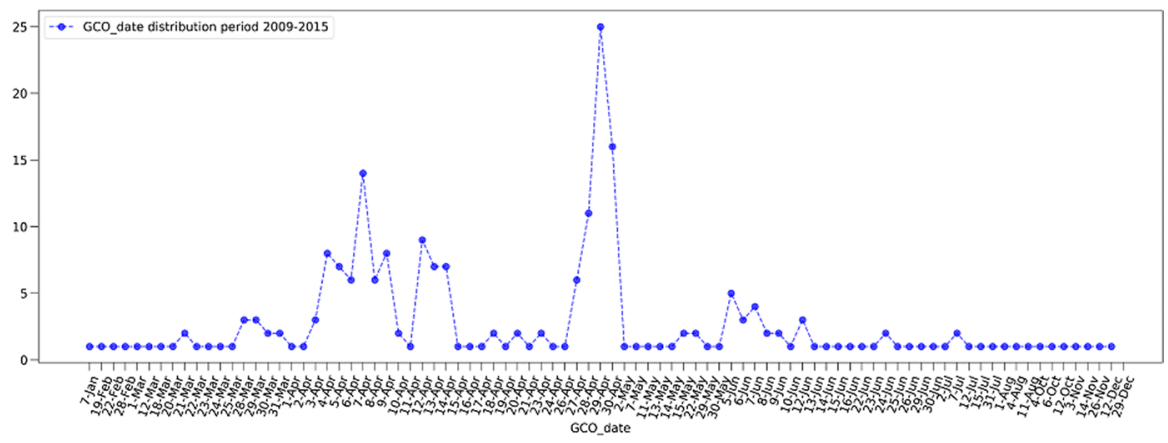

Fig. 3 Distribution of events' dates (GCO Release) during years. Time distribution of events during the year (January-December) relate to 2009-2015 (total obs. 235)
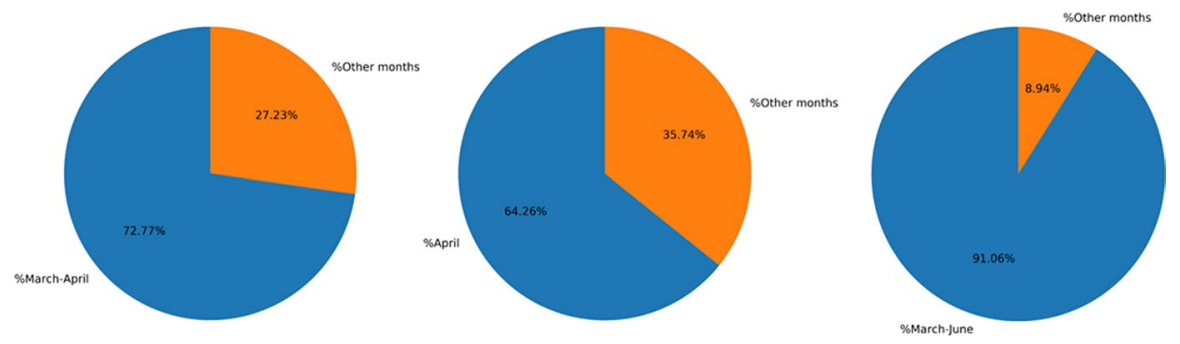

Fig. 4 Basic statistics of Events' Distribution (GCO). Percentage of the events' distribution during the principal months (March-April/March-June/April) and during the remainder of the year

\subsection{The event study approach}

This section focuses on the design and statistical properties of the ES applied. As previously specified, via ES and related statistical tests, the dynamics of listed firms' stock prices at and around the release of audit reports containing a GCM are analysed. The main idea is that the magnitude of abnormal returns at the time of the release of audit reports might provide a measure of the impact of these events on the wealth of firms' claimholders (see Campbell et al. (1997) and the references therein for a complete survey on the ES approach).

At the same time, the ES allows us to test the efficiency of the Italian stock market since abnormal stock returns different from zero and persisting after the release of an audit report are inconsistent with market efficiency (Fama 1991).

As in a classical ES, we analyse the behaviour of returns for a sample of Italian listed firms that received a GCM in their audit reports during the period 2009-2015. As inferred from previous sections, this type of event is mainly clustered in the period of the year starting from the beginning of March to the end of June. Therefore, there is the risk that other confounding events may drive the abnormal returns ultimately detected. However, looking at the exact time distribution of each event considered (see Figs. 3 and 4), 72.77\% of events are clustered in the period to 1st March to 30th April, and $64,26 \%$ are clustered in the month of April. Indeed, the distribution of events allows us 
to further resizes the possibility that other events might have driven abnormal returns. Finally, we detected 20 observations where the audit report release was not in the period 1st March-30th June. This is due to aspects such as different fiscal year ends, bankruptcy procedures or single firm administrative lags. However, considering their low incidence (9\%), we decided to keep these observations in the sample. The time displacement of the events considered should preserve the hypothesis of cross-sectional independence underlying the ES since the event date is not common to all the firms in the sample. Because the regulatory improvement of 2009 asks for an immediate and separate press release when an audit report contains a GCM, the audit report date represents the first date on which information is available to FSs users.

\subsection{Design and statistical tests}

To compute abnormal returns (ARs), for each firm $i$ included in both the main and matched samples, we compute the observed daily log-returns with the expected returns, which are estimated by using the classical linear model:

$$
R_{i t}=\alpha_{i}+\beta_{i} R I t+\varepsilon_{i t}, \quad \varepsilon_{i t} \sim N\left(0, \sigma_{i}^{2}\right), \quad t \in E P
$$

where $R_{i t}$ is the return of firm $i$ observed at time $t ; R_{I t}$ is the return of a weighted stock index at time, and $\alpha_{i}, \beta_{i} \in R$ are parameters estimated over a period of "normal behaviour", i.e., the estimation period (EP) starting 200 days before the event date and ending 15 days before.

The stock index used in (1) takes into account both samples, and it is calculated by using as weight each firm's market capitalization. This way of proceeding allows us to better test investor reactions, compared to considering the main Italian stock market index (FTSE MIB), which is composed only of the top 40 Italian listed companies in terms of market capitalization, floating shares and liquidity and may therefore not be representative of the financially distressed companies included in our main sample. Indeed, following Hitchner (2017, p. 1038), "One also may include returns from individual comparable companies (assuming that such returns would not have been affected by the corrective disclosure at issue) or construct a custom index, especially if a representative index is not available or if the security at issue represents a significant component of the industry index". This allows us to calculate stock abnormal returns based on the weighted stock index, improving the accuracy of the study and the conclusions that may be obtained.

Let $t=0$ represent the event date; ARs are then estimated in the test period, which is set equal to 30 trading days around each event, TP $=[-15,0) \cup(0,+15]$, and then divided into several subintervals. In particular, we focus on the following windows: $[-15 ;-10) ;(-2,+2) ;(+2 ;+15]$ and $[-1,1]$. The first three windows are further split into $[-15 ;-2) ;(-10 ;-5) ;(-5,-1) ;(+1,+5) ;(+5,+10) ;(+10,+15]$, while the latter are split into $(-1,0) ;(0) ;(0,+1)$ for a fine-tuning of the analysis in proximity of the event date. These windows are tied to our willingness to check not only whether the disclosure of audit reports impacts stock prices, but also whether the market anticipates (or not) the release of auditor opinions. 
For each stock $i$, ARs are defined as the difference between the observed returns around the day of the event, $t=0$, and the return predicted by the model in (1):

$$
A R_{i t}=R_{i t}-\left(\hat{\alpha}_{i}+\hat{\beta}_{i} R_{I t}\right), \quad t \in T P
$$

where $\hat{\alpha}_{i}{ }^{\prime} s$ and $\hat{\beta}_{i}{ }^{\prime} s$ are the estimated parameters of the model for each firm i.

In other words, $A R_{i t}{ }^{\prime} s$ measures the difference between the conditional returns at the event and the expected unconditional returns at the event. In doing so, abnormal returns might also highlight the change in wealth of stockholders related to the event.

To perform the analysis and to verify whether or not audit reports impact on stock prices $\left(H_{0}\right.$ : there are no ARs within the TP; $H_{1}$ : presence of ARs within the TP), first, the cross-sectional means of ARs are computed for each $t \in T P$ :

$$
\overline{A R}_{t}=\frac{1}{N} \sum_{i=1}^{N} A R_{i t}
$$

with $\mathrm{N}$ representing the number of firms included in the sample.

Then, the cross-sectional mean of the cumulative abnormal returns, $\overline{C A R}_{t_{a} t_{b}}$, are computed over each subinterval, $\left(t_{a}, t_{b}\right) \in T P$ :

$$
\overline{\operatorname{CAR}}_{t_{a} t_{b}}=\sum_{t=t_{a}}^{t_{b}} \overline{A R}_{t}
$$

To obtain robust results, we apply the Mikkelson and Partch (MP) test (1988), in which a factor for each company of the sample is applied to correct the bias induced by the presence of serial correlation in the returns:

$$
Z_{\overline{C A R_{t_{a} t_{b}}}}^{M P}=\frac{1}{\sqrt{N}} \sum_{i=1}^{N}\left[C A R_{i, t_{a} t_{b}} / \sqrt{\sigma_{C A R_{i, t_{a} t_{b}}}^{2}}\right]
$$

where $\sigma_{\overline{C A R}_{i, t_{a}, t_{b}}^{2}}^{2}=\sigma_{\overline{A R}_{E P}}^{2}\left[T+\frac{T^{2}}{T_{E P}}+\frac{\sum_{t=t_{a}}^{t_{b}} R_{M t}-T\left(\bar{R}_{M}\right)^{2}}{\sum_{t_{E P}=1}^{T_{E P}}\left(R_{M t}-\bar{R}_{M}\right)^{2}}\right]$ is the variance in the cumulated prediction error of firm $i$, where $\sigma_{\overline{A R}_{E P}}^{2}$ is the residual variance in the market model regression for firm i; $T=t_{b}-t_{a}+1$ is the number of days in the window; $T_{E P}$ is the number of days in the period used to estimate the model; $R_{I t}$ is the weighted index return at time $\mathrm{t}$; and $\bar{R}_{I}$ is its average in the estimation period.

Its higher reliability notwithstanding, the MP test has been modified over time to correct for the cross-sectional correlation in abnormal returns. In this respect, Boehmer et al. (1991), Mentz and Schiereck (2008) and Kolari and Pynnönen (2010) have made relevant improvements. First, Mentz and Schiereck (2008), based on Boehmer et al. (1991), calculated security i's standardized residual on the event day (SRi) as:

$$
S R i=C A R_{i, t_{a} t_{b}} / \sqrt{\sigma_{\text {CAR }_{i, t_{a} t_{b}}^{2}}^{2}}
$$


and then used (7) to calculate a $\mathrm{Z}$ statistic (here, called $\mathrm{Z}_{\mathrm{M}}$ ):

$$
Z_{M}=\frac{1}{N} \sum_{i=1}^{N} S R i / \sqrt{\frac{1}{N(N-1)} \sum_{i=1}^{N}\left(S R i-\sum_{i=1}^{N} \frac{S R i}{N}\right)^{2}}
$$

Finally, (Kolari and Pynnönen 2010) proposed a new statistic test (hereafter, MP corrected) that further modifies that proposed by Boehmer et al. (1991), introducing $h=\sqrt{\frac{1-\bar{\rho}}{1+(N-1) \bar{\rho}}}$, that is, a correction factor to the above defined $\mathrm{Z}^{\mathrm{M}}$ where $\bar{\rho}$ is the average of the sample cross-correlations of the estimation period residuals and $\mathrm{N}$ is the number of observations in the sample considered. This last test is the test used by Ianniello and Galloppo (2015).

We perform the ES and related statistical tests assuming a linear model. However, according to the Breusch-Pagan test, almost $40 \%$ of the AR series present heteroscedasticity, and a high cross-sectional asymmetry is detected in the distribution of ARs. The two statistical tests used in the ES framework adopted allow us to support the reliability of our conclusions, especially when the results are similar between them. After all, the Durbin-Watson cross-sectional test confirms the absence of cross-correlation, while the endogeneity test is very close to zero, indicating that the variables are exogenous with respect to the error term.

Finally, to increase the robustness of our results and methodology, we repeated the ES by replacing in the calculation of ARs the FTSE MIB with $R_{M I t}$ within the framework of the linear market model. We obtained similar but rougher results. To demonstrate the similar trends that the use of the two stock indexes determines, we applied a paired-sample $t$ test on the CARs between the two groups. The results of the paired-sample t-test on the independent samples are shown in the Appendix 2.

\section{Findings}

Of the 235 firms/observations with GCMs, we assigned a series of numerical labels to distinguish unqualified opinions containing GCMs (1), except for (2), disclaimers of opinion (3) and adverse opinions (4). Then, we first tested all categories as a whole (all GCMs, 1-2-3-4), then each category separately $(1,2,3)$, with the exception of adverse opinions (4), for which we had only 2 firms/observations in the period investigated (see Table 2), and, finally, for the " 234 " category encompassing all categories, with the exception of unqualified opinions containing GCMs.

Table 5 shows the results of each test and Fig. 5 the CARs distribution of the 235 observations in each sub-window investigated.

First, it is important to stress that when statistical tests are significant, we find a systematic negative impact of GCMs on stock prices, with two isolated exceptions that present a CAR percentage lower than 50\%. This evidence confirms H1. The information content of audit reports partially corroborates the results achieved by Ianniello and Galloppo (2015), with some exceptions. Considering the group with all GCMs, we find a persistent negative investor reaction in the majority of the windows analysed. As showed 


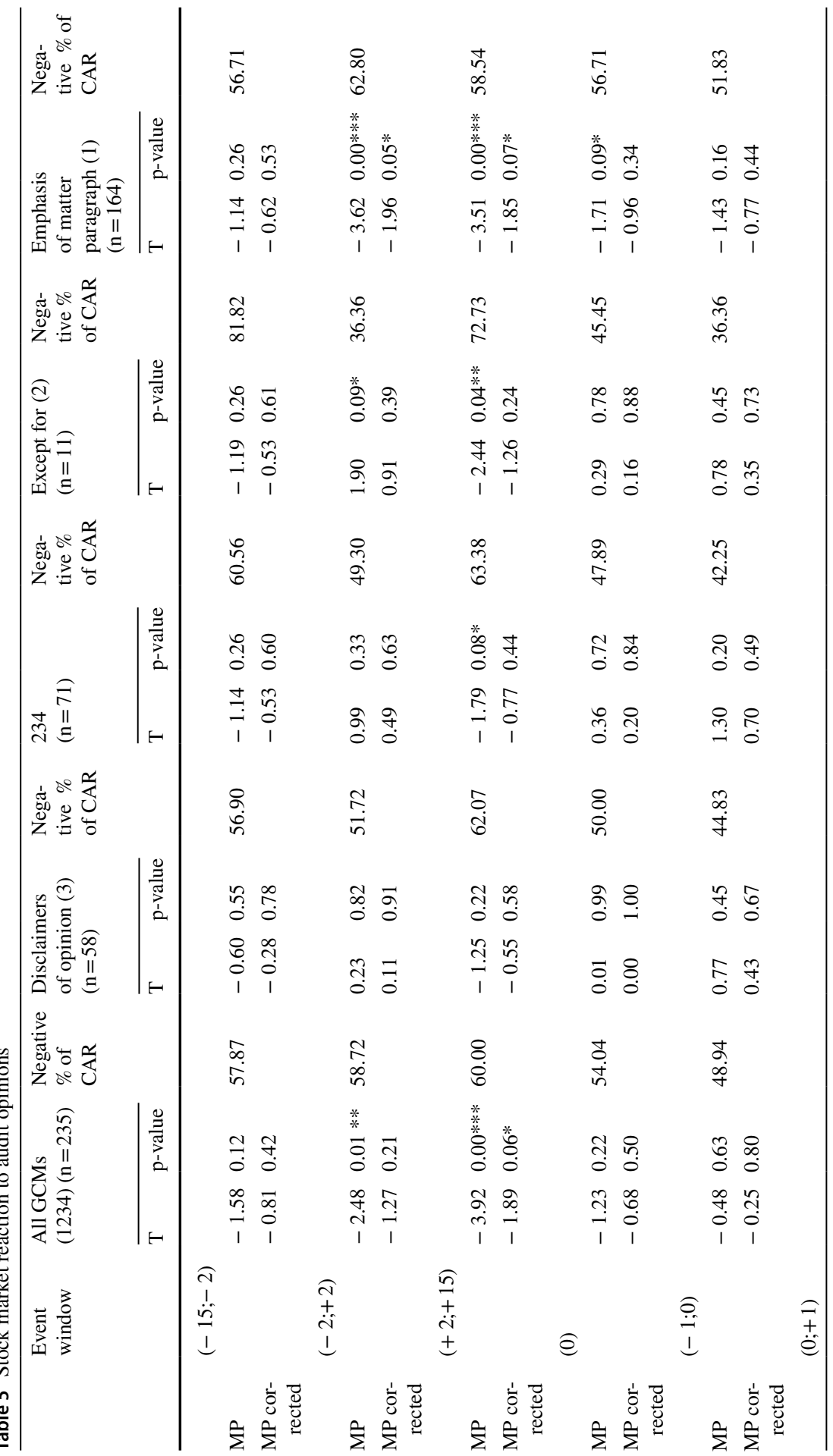




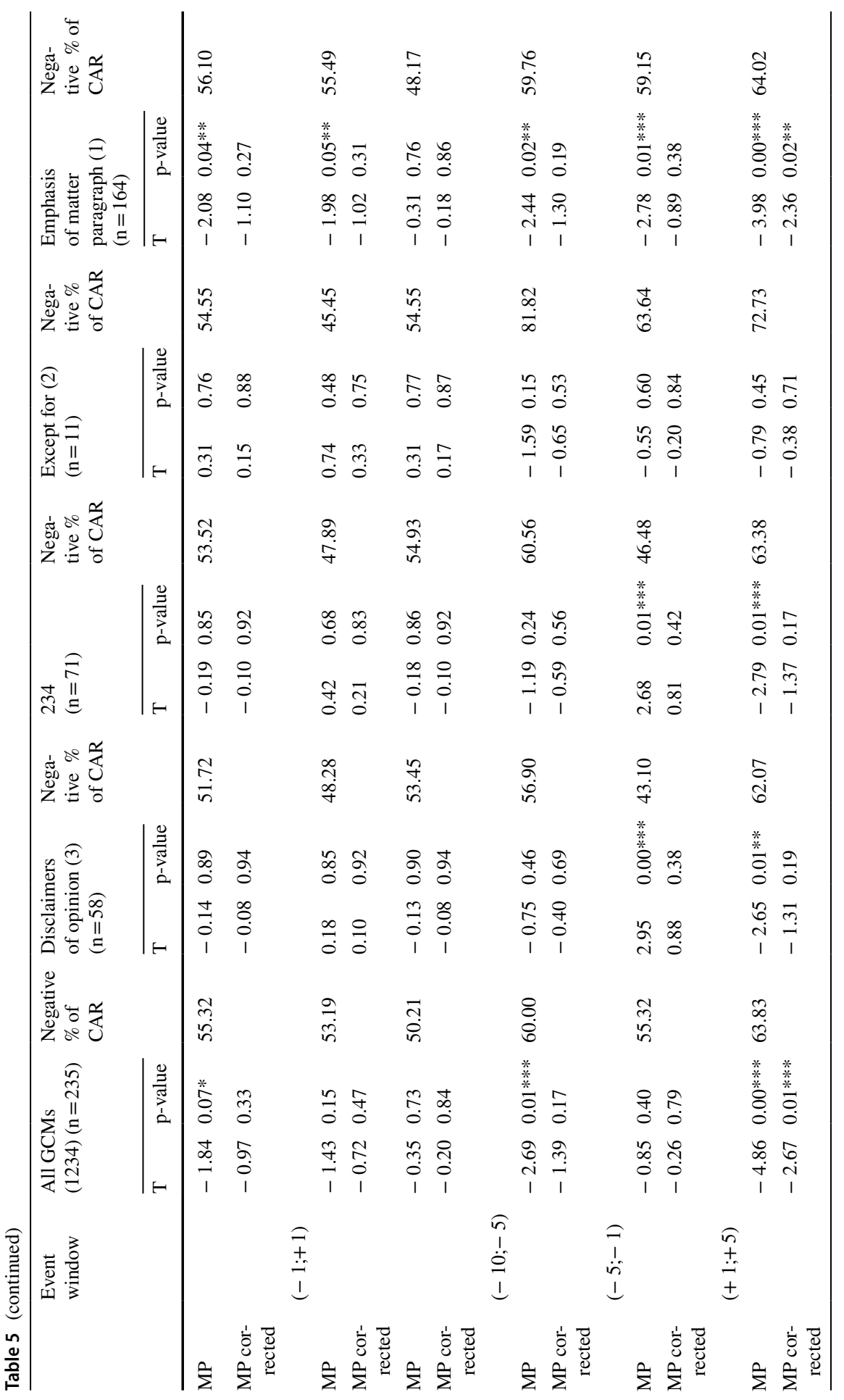




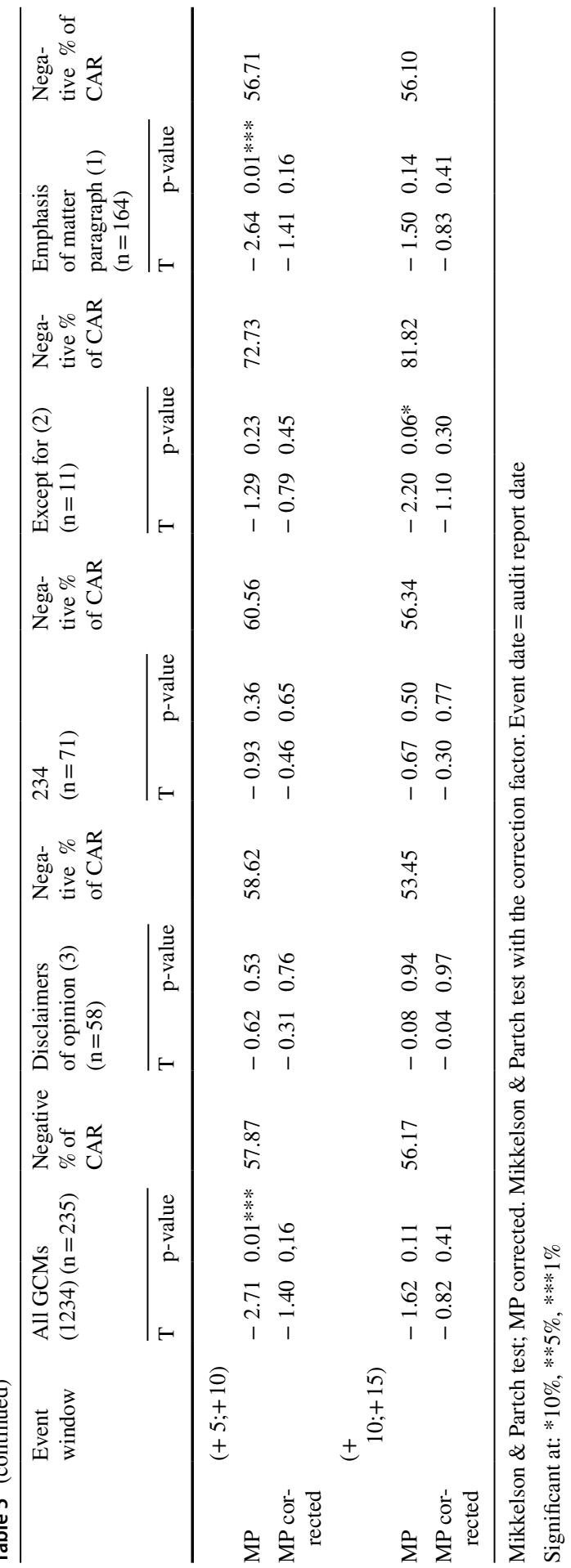



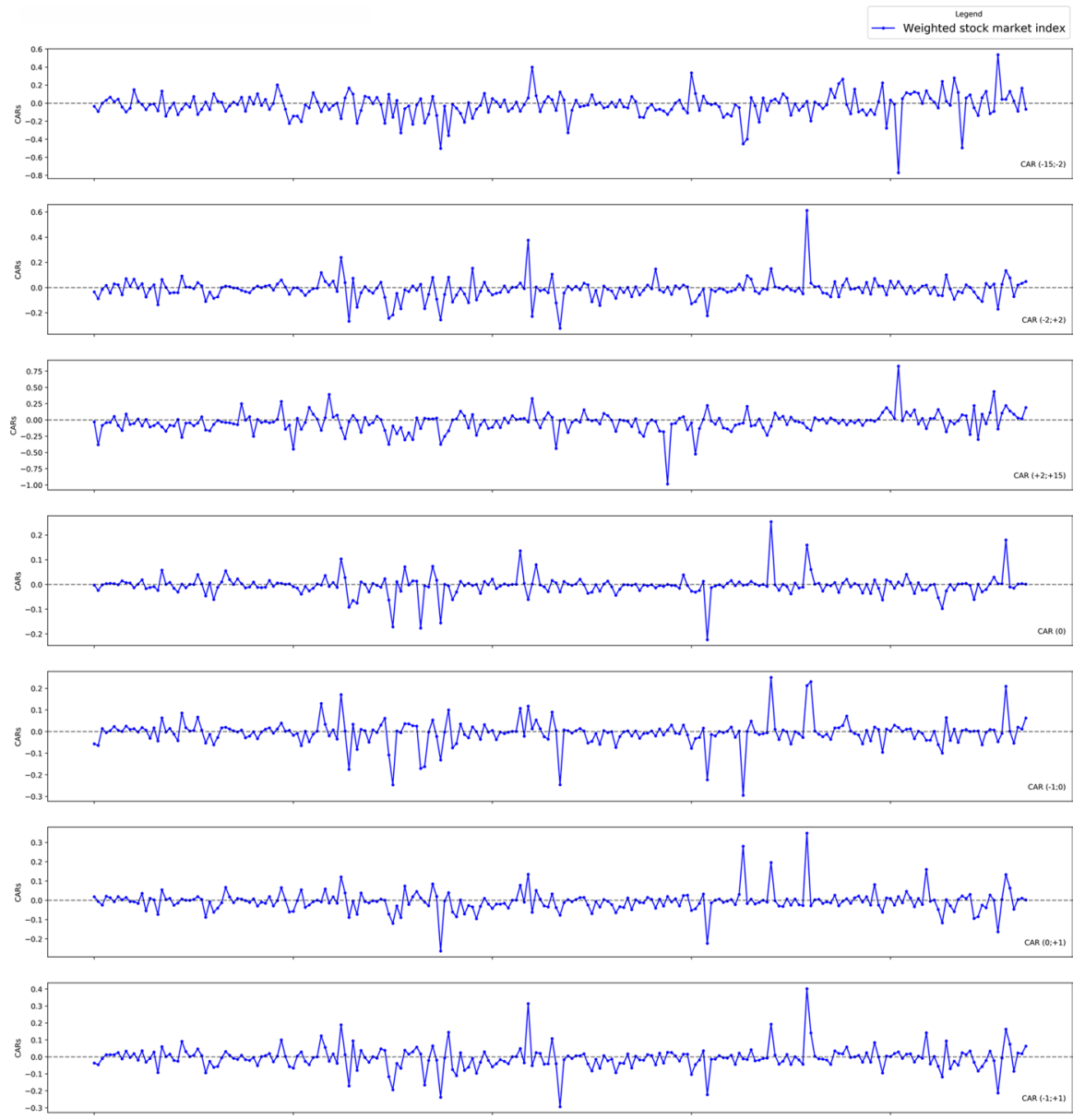

Fig. 5 CARs distribution of the 235 observations in each sub-window investigated, using the weighted stock index

by Ianniello and Galloppo (2015), prior to the regulatory upgrades, investors reacted negatively only to GCMs attached to qualified opinions. In fact, in the case of unqualified opinions with GCMs, these authors find a positive market reaction. Considering an extended and more homogeneous period, as in our study, the latter category inverts its information value, making GCMs associated with unqualified opinions be something that is systematically negative for the Italian stock market. In other words, an unqualified opinion with a GCM has shifted over time from good news to bad news, at least around and after the release of the audit report. Thus, $\mathrm{H} 2$ is confirmed.

Going further, we analyse different main windows and sub-windows to investigate the impact prior to, at, around and following the event date.

A pre-disclosure effect is detected only in the sub-window $(-10,-5)$ under the MP test for the whole group of GCMs, but it is entirely due to unqualified opinions with GCMs. A positive effect prior to the event date $(-5,-1)$ is identified only in 

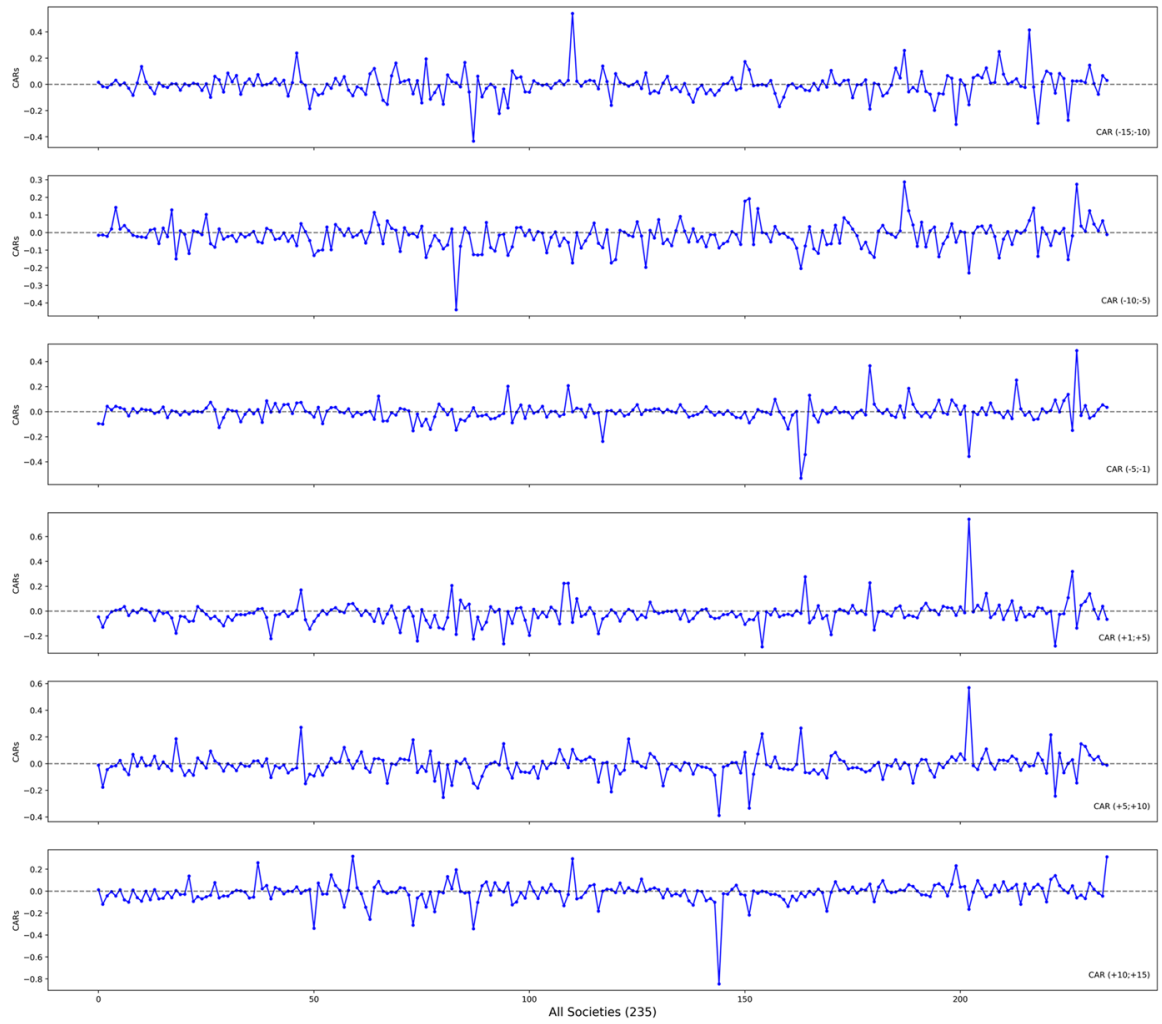

Fig. 5 (continued)

the case of the "234" and " 3 " categories, but it is detected only for the MP test, and looking at the percentage of negative CARs, we find that they are higher than $40 \%$ (46\% and $43 \%$, respectively), which is still remarkable. In contrast, a negative effect is detected (associated with a high percentage of negative CARs) in the same subwindow for unqualified opinions with GCMs. This evidence further confirms H2.

Observing the days around the event date, we find that the results are statistically significant for unqualified opinions with GCMs in all sub-windows and for "all GCMs" only in the sub-window $(0,+1)$. However, it should be noted that none of this evidence is confirmed when applying the correction factor to the basic MP test.

Finally, we identify a strong negative post-announcement effect. However, the results are mixed with regard to different categories of GCMs excluding observations related to "except for" opinions. More specifically, a significant negative effect is detected for unqualified opinions with GCM in the sub-window $(+1,+5)$ for both MP and MP corrected test and in the sub-window $(+5,+10)$ for the MP test solely. In all these cases, the percentage of negative CARs is always higher than $62 \%$, increasing the value of our results. 
To the best of our knowledge, it is clear that, at least for Italy and based on these results, regulatory updates in the wake of the continuing financial crisis have led to a persistent negative investor reaction to all categories of GCMs, with the important majority being unqualified opinions with GCMs.

Table 6 provides the findings for the test of $\mathrm{H} 3$ and shows the results of the effects of first-time GCMs and recurring GCMs.

Additionally, in this case, the results, when significant, reveal a negative reaction for both first-time and recurring GCMs. However, the significance is importantly higher for recurring GCMs. First-time GCMs lead to negative reactions only in the main window around the event date $(-2,+2)$ and in the sub-window $(+1,+5)$. In contrast, recurring GCMs show an equal or higher significance in the same window and sub-window plus others, namely, $(+2 ;+15](-10,-5)(+5,+10)$ and $(+10$, $+15)$. Notably, these effects are confirmed by the MP corrected test in the main window $(+2 ;+15]$ and in the subwindow $(+1,+5)$. Thus, contrary to expectations, $\mathrm{H} 3$ is rejected. We attribute these results, first, to the sample composition. In fact, the number of observations (182) included in recurring GCM subsample observations is decisively higher than that included in the first-time GCM subsample observations (53). In addition, in the Italian context, as is well known, since minority shareholders do not have privileged access to company information (Nobes and Parker 2016; Solomon 2017), they persist in reacting negatively when a GCM is confirmed over time probably because the GCM is perceived as a more severe opinion.

\subsection{Additional tests}

\subsubsection{Blacklisted companies}

In Italy, according to art. 114 TUF, listed issuers are obligated to disclose some important information to the market with a method regulated by CONSOB. The "CONSOB Blacklist", which refers to the set of listed companies that are subject to more frequent obligations of information disclosure, was established in 2002. Inclusion in the blacklist is decided by CONSOB based on two elements symptomatic of important financial tensions:

- when a company incurs losses of more than $1 / 3$ of its equity and

- when auditors express doubts about a company's GC other than those expressed by the management, which automatically determine a GCM in the audit report.

Thus, we perform an additional test focusing on this aspect. ${ }^{2}$ During the period under investigation, 23 firms among those analysed were included in the "blacklist", representing 83 observations over the total sample (235). We repeat the ES test, analysing the blacklisted companies separately from the others. The results are shown in Table 7.

\footnotetext{
${ }^{2}$ We do not consider the differences in the investor reaction to GCMs issued to firms that subsequently declare bankruptcy compared to those that survive (as studied by, among others, Blay and Geiger (2001)) because only 14 out of the 68 companies in our final sample declared bankruptcy.
} 
Table 6 Stock reactions to first and second (or multiple) GCMs

\begin{tabular}{|c|c|c|c|c|c|c|c|}
\hline & \multirow[t]{2}{*}{$\begin{array}{l}\text { Event win- } \\
\text { dow }\end{array}$} & \multicolumn{2}{|c|}{$\begin{array}{l}\text { First-time GCM } \\
(\mathrm{n}=53)\end{array}$} & \multirow[t]{2}{*}{$\begin{array}{l}\text { Negative \% } \\
\text { of CAR }\end{array}$} & \multicolumn{2}{|c|}{$\begin{array}{l}\text { Recurring GCM } \\
(\mathrm{n}=182)\end{array}$} & \multirow[t]{2}{*}{$\begin{array}{l}\text { Negative } \% \\
\text { of CAR }\end{array}$} \\
\hline & & $\mathrm{T}$ & $\mathrm{p}$-value & & $\mathrm{T}$ & $\mathrm{p}$-value & \\
\hline & $(-15 ;-2)$ & & & & & & \\
\hline MP & & 0.59 & 0.56 & 54.72 & -2.11 & $0.04 * *$ & 58.79 \\
\hline MP corrected & $(-2 ;+2)$ & 0.34 & 0.74 & & -1.09 & 0.28 & \\
\hline MP & & -1.97 & $0.05^{*}$ & 66.04 & -1.76 & $0.08^{*}$ & 56.59 \\
\hline MP corrected & $(+2 ;+15)$ & -1.09 & 0.28 & & -0.91 & 0.36 & \\
\hline MP & & -1.38 & 0.17 & 56.60 & -3.71 & $0.00 * * *$ & 60.99 \\
\hline MP corrected & (0) & -0.82 & 0.41 & & -1.76 & $0.08 *$ & \\
\hline MP & & -0.14 & 0.89 & 50.94 & -1.33 & 0.19 & 54.95 \\
\hline MP corrected & $(-1 ; 0)$ & -0.08 & 0.94 & & -0.74 & 0.46 & \\
\hline MP & & -0.13 & 0.89 & 47.17 & -0.47 & 0.64 & 49.45 \\
\hline MP corrected & $(0 ;+1)$ & -0.07 & 0.94 & & -0.25 & 0.80 & \\
\hline MP & & -1.39 & 0.17 & 62.26 & -1.34 & 0.18 & 53.30 \\
\hline MP corrected & $(-1 ;+1)$ & -0.83 & 0.41 & & -0.70 & 0.48 & \\
\hline MP & & -1.25 & 0.22 & 60.38 & -0.95 & 0.34 & 51.10 \\
\hline MP corrected & $(-15 ;-10)$ & -0.70 & 0.49 & & -0.48 & 0.63 & \\
\hline MP & & 1.25 & 0.22 & 43.40 & -1.08 & 0.28 & 52.20 \\
\hline MP corrected & $(-10 ;-5)$ & 0.77 & 0.44 & & -0.62 & 0.54 & \\
\hline MP & & -0.55 & 0.59 & 52.83 & -2.76 & $0.01 * * *$ & 62.09 \\
\hline MP corrected & $(-5 ;-1)$ & -0.30 & 0.77 & & -1.45 & 0.15 & \\
\hline MP & & -1.06 & 0.29 & 58.49 & -0.39 & 0.69 & 54.40 \\
\hline MP corrected & $(+1 ;+5)$ & -0.33 & 0.75 & & -0.13 & 0.90 & \\
\hline MP & & -2.79 & $0.01 * * *$ & 69.81 & -4.02 & $0.00 * * *$ & 62.09 \\
\hline MP corrected & $(+5 ;+10)$ & -1.60 & 0.12 & & -2.26 & $0.03 * *$ & \\
\hline MP & & -1.32 & 0.19 & 54.72 & -2.37 & $0.02 * *$ & 58.79 \\
\hline MP corrected & $(+10 ;+15)$ & -0.86 & 0.39 & & -1.19 & 0.24 & \\
\hline MP & & 0.82 & 0.42 & 50.94 & -2.28 & $0.02 * *$ & 57.69 \\
\hline MP corrected & & 0.49 & 0.63 & & -1.16 & 0.25 & \\
\hline
\end{tabular}

Mikkelson \& Partch test; MP corrected, Mikkelson \& Partch test with the correction factor. Event date $=$ audit report date. A total of 53 observations are companies that received a first-time GCM; 182 observations are companies that received a second (or more) GCM

Significant at: $* 10 \%, * * 5 \%, * * * 1 \%$ 
For both categories, a negative market reaction is detected, but this reaction is reiterated for almost all windows and sub-windows for the "blacklisted companies". However, the adverse reaction to the blacklist is largely stronger than that to companies not included in the list. As happened in the case of the main tests, the percentage of negative CARs (when we register a significant negative reaction) is also higher than $55 \%$. We conclude that investors seriously take into consideration the regulatory requirements and institutional prescriptions. In addition, Italy is an insider economy encircled by debtor-friendly countries, and the majority of its listed firms are family owned or have concentrated ownership. Thus, negative abnormal returns are the result of minority investors' disinvestment decisions. Indeed, minority shareholders prefer to express their dissatisfaction by selling their shares rather than through voice (Solomon 2017). Seen through these lenses, it is clear that the behaviour of minority investors is similar to that of "creditors", responding more severely to GCMs than investors in larger stock markets with higher dispersed ownership or in other debtor-friendly countries where the primary interest agreed by law is more in favour of owners (see Kausar et al. 2017). Ultimately, the effects of the implications of the so-called type II agency problem (majority shareholders vs. minority shareholders) seem to be effective in explaining the more severe reaction found for Italian blacklisted companies.

\subsubsection{Big 4 auditors and non-Big 4 auditors}

To foster a complete picture, we further split the GCM sample to distinguish between firms audited by Big 4 auditors and firms audited by other audit companies. We identified 163 observations in the first category and 72 observations in the second. The results of the ES according to this partition are shown in Table 8 .

In both cases, a negative market reaction is detected, especially after the event date. However, analysing more in depth, we find that the reaction is weakly stronger in the case of auditing services provided by a non-Big 4 firm (see both the significance and CAR \% of the tests), especially in the period around the event date. As highlighted above, Italian investors suffer weak protection, which is reflected in the lack of trust in the work of auditors, especially in the case of Big 4 companies. Previous studies have shown that Big 4 auditors were characterized by higher audit quality, as demonstrated by their propensity to easily issue GCMs or other audit report modifications (DeFond et al. 2000; Francis and Yu 2009; Geiger and Rama 2006; Lennox 1999; Menon and Williams 2010). On the other hand, Hunt and Lulseged (2007) found that non-Big 5 auditors, like Big 5 auditors, have a similar likelihood of issuing a GCM to their potentially financially distressed clients, regardless of size. Finally, our results are in line with those of Cameran et al. (2010), who did not find that in Italy, Big 4 auditors as a group enjoy a better reputation among customers than other audit firms as a group. Thus, not surprisingly, investors reacted more negatively to GCMs released by small and medium-sized audit firms for which the issuance of a GCM can result in a higher likelihood of resigning (Chow and Rice 1982; Krishnan et al. 1996; Vanstraelen 2003). In fact, as is well known, the bargaining power of small and medium-sized audit firms is lower than that of large audit firms. Moreover, in the Italian setting, audit firms are forbidden to provide non-audit 
Table 7 Stock reaction to blacklisted companies vs. not blacklisted companies

\begin{tabular}{|c|c|c|c|c|c|c|c|}
\hline & \multirow[t]{2}{*}{ Event window } & \multicolumn{2}{|c|}{$\begin{array}{l}\text { Blacklisted companies } \\
(\mathrm{n}=83)\end{array}$} & \multirow[t]{2}{*}{$\begin{array}{l}\text { Negative \% } \\
\text { of CAR }\end{array}$} & \multicolumn{2}{|c|}{$\begin{array}{l}\text { Not blacklisted compa- } \\
\text { nies }(n=152)\end{array}$} & \multirow[t]{2}{*}{$\begin{array}{l}\text { Negative \% } \\
\text { of CAR }\end{array}$} \\
\hline & & $\mathrm{T}$ & p-value & & $\mathrm{T}$ & p-value & \\
\hline & $(-15 ;-2)$ & & & & & & \\
\hline MP & & -2.27 & $0.03 * *$ & 59.04 & -0.22 & 0.83 & 57.24 \\
\hline MP corrected & & -1.17 & 0.25 & & -0.11 & 0.91 & \\
\hline & $(-2 ;+2)$ & & & & & & \\
\hline MP & & -1.67 & $0.10^{*}$ & 56.63 & -1.65 & 0.10 & 59.21 \\
\hline MP corrected & & -0.95 & 0.35 & & -0.81 & 0.42 & \\
\hline & $(+2 ;+15)$ & & & & & & \\
\hline MP & & -2.41 & $0.02 * *$ & 59.04 & -2.73 & $0.01 * * *$ & 59.21 \\
\hline MP corrected & & -1.16 & 0.25 & & -1.35 & 0.18 & \\
\hline & $(0)$ & & & & & & \\
\hline MP & & -2.52 & $0.01^{* *}$ & 63.86 & 0.33 & 0.75 & 48.68 \\
\hline MP corrected & & -1.46 & 0.15 & & 0.18 & 0.86 & \\
\hline & $(-1 ; 0)$ & & & & & & \\
\hline MP & & -2.21 & $0.03 * *$ & 57.83 & 1.07 & 0.29 & 44.08 \\
\hline MP corrected & & -1.28 & 0.20 & & 0.55 & 0.58 & \\
\hline & $(0 ;+1)$ & & & & & & \\
\hline MP & & -1.37 & 0.17 & 53.01 & -1.10 & 0.27 & 55.92 \\
\hline MP corrected & & -0.77 & 0.45 & & -0.57 & 0.57 & \\
\hline & $(-1 ;+1)$ & & & & & & \\
\hline MP & & -1.59 & 0.12 & 53.01 & -0.48 & 0.63 & 52.63 \\
\hline MP corrected & & -0.88 & 0.38 & & -0.23 & 0.81 & \\
\hline & $(-15 ;-10)$ & & & & & & \\
\hline MP & & -1.92 & $0.06^{*}$ & 59.04 & 0.97 & 0.33 & 46.05 \\
\hline MP corrected & & -1.15 & 0.25 & & 0.54 & 0.59 & \\
\hline & $(-10 ;-5)$ & & & & & & \\
\hline MP & & -2.16 & $0.03 * *$ & 62.65 & -1.77 & $0.08^{*}$ & 59.87 \\
\hline MP corrected & & -1.23 & 0.22 & & -0.88 & 0.38 & \\
\hline & $(-5 ;-1)$ & & & & & & \\
\hline MP & & -3.61 & $0.00^{* * *}$ & 65.06 & 1.83 & $0.07 *$ & 50.00 \\
\hline MP corrected & & -1.24 & 0.22 & & 0.55 & 0.58 & \\
\hline & $(+1 ;+5)$ & & & & & & \\
\hline MP & & -2.02 & $0.05^{* *}$ & 56.63 & -4.42 & $0.00^{* * *}$ & 67.76 \\
\hline MP corrected & & -1.19 & 0.24 & & -2.43 & $0.02 * *$ & \\
\hline & $(+5 ;+10)$ & & & & & & \\
\hline MP & & -1.89 & $0.06^{*}$ & 63.86 & -1.62 & 0.11 & 53.29 \\
\hline MP corrected & & -1.00 & 0.32 & & -0.83 & 0.41 & \\
\hline & $(+10 ;+15)$ & & & & & & \\
\hline MP & & -1.88 & $0.06^{*}$ & 55.42 & -0.51 & 0.61 & 55.92 \\
\hline MP corrected & & -1.01 & 0.32 & & -0.26 & 0.80 & \\
\hline
\end{tabular}

Mikkelson \& Partch test; MP corrected, Mikkelson \& Partch test with the correction factor. Event date $=$ audit report date. A total of 83 observations are included in the black or grey list of CONSOB; 152 observations are not included in the black or grey list of CONSOB

Significant at: $* 10 \%, * * 5 \%, * * * 1 \%$ 
Table 8 Stock reaction to Big 4 auditors or non-Big 4 auditors

\begin{tabular}{|c|c|c|c|c|c|c|c|}
\hline & \multirow[t]{2}{*}{ Event window } & \multicolumn{2}{|c|}{$\begin{array}{l}\text { Big } 4 \text { auditors } \\
(\mathrm{n}=163)\end{array}$} & \multirow[t]{2}{*}{$\begin{array}{l}\text { Negative \% } \\
\text { of CAR }\end{array}$} & \multicolumn{2}{|c|}{$\begin{array}{l}\text { Non- Big } 4 \text { auditors } \\
(\mathrm{n}=72)\end{array}$} & \multirow[t]{2}{*}{$\begin{array}{l}\text { Negative } \% \\
\text { of CAR }\end{array}$} \\
\hline & & $\mathrm{T}$ & p-value & & $\mathrm{T}$ & $\mathrm{p}$-value & \\
\hline & $(-15 ;-2)$ & & & & & & \\
\hline MP & & -1.13 & 0.26 & 57.67 & -1.15 & 0.25 & 58.33 \\
\hline \multirow[t]{2}{*}{ MP corrected } & & -0.57 & 0.57 & & -0.62 & 0.54 & \\
\hline & $(-2 ;+2)$ & & & & & & \\
\hline MP & & -0.78 & 0.44 & 55.21 & -3.32 & $0.00 * * *$ & 66.67 \\
\hline \multirow[t]{2}{*}{ MP corrected } & & -0.40 & 0.69 & & -1.76 & $0.08^{*}$ & \\
\hline & $(+2 ;+15)$ & & & & & & \\
\hline MP & & -3.53 & $0.00 * * *$ & 59.51 & -1.77 & $0.08 *$ & 61.11 \\
\hline \multirow[t]{2}{*}{ MP corrected } & & -1.69 & $0.09 *$ & & -0.90 & 0.37 & \\
\hline & $(0)$ & & & & & & \\
\hline MP & & -0.55 & 0.58 & 52.15 & -1.40 & 0.16 & 58.33 \\
\hline \multirow[t]{2}{*}{ MP corrected } & & -0.30 & 0.76 & & -0.80 & 0.43 & \\
\hline & $(-1 ; 0)$ & & & & & & \\
\hline MP & & 0.81 & 0.42 & 44.17 & -2.07 & $0.04 * *$ & 59.72 \\
\hline \multirow[t]{2}{*}{ MP corrected } & & 0.43 & 0.67 & & -1.14 & 0.26 & \\
\hline & $(0 ;+1)$ & & & & & & \\
\hline MP & & -1.08 & 0.28 & 52.76 & -1.69 & $0.09 *$ & 61.11 \\
\hline \multirow[t]{2}{*}{ MP corrected } & & -0.56 & 0.58 & & -0.97 & 0.34 & \\
\hline & $(-1 ;+1)$ & & & & & & \\
\hline MP & & -0.08 & 0.93 & 50.31 & -2.45 & $0.02 * *$ & 59.72 \\
\hline \multirow[t]{2}{*}{ MP corrected } & & -0.04 & 0.97 & & -1.34 & 0.18 & \\
\hline & $(-15 ;-10)$ & & & & & & \\
\hline MP & & -0.22 & 0.83 & 49.08 & -0.30 & 0.76 & 52.78 \\
\hline \multirow[t]{2}{*}{ MP corrected } & & -0.12 & 0.90 & & -0.19 & 0.85 & \\
\hline & $(-10 ;-5)$ & & & & & & \\
\hline MP & & -1.83 & $0.07 *$ & 59.51 & -2.11 & $0.04 * *$ & 61.11 \\
\hline \multirow[t]{2}{*}{ MP corrected } & & -0.88 & 0.38 & & -1.39 & 0.17 & \\
\hline & $(-5 ;-1)$ & & & & & & \\
\hline MP & & 0.54 & 0.59 & 53.37 & -2.35 & $0.02 * *$ & 59.72 \\
\hline \multirow[t]{2}{*}{ MP corrected } & & 0.17 & 0.86 & & -0.69 & 0.49 & \\
\hline & $(+1 ;+5)$ & & & & & & \\
\hline MP & & -3.21 & $0.00^{* * *}$ & 60.12 & -3.96 & $0.00^{* * *}$ & 72.22 \\
\hline \multirow[t]{2}{*}{ MP corrected } & & -1.76 & $0.08^{*}$ & & -2.25 & 0.03 & \\
\hline & $(+5 ;+10)$ & & & & & & \\
\hline MP & & -1.87 & $0.06^{*}$ & 57.06 & -2.09 & 0.04 & 59.72 \\
\hline \multirow[t]{2}{*}{ MP corrected } & & -0.95 & 0.35 & & -1.15 & 0.25 & \\
\hline & $(+10 ;+15)$ & & & & & & \\
\hline MP & & -1.81 & $0.07 *$ & 58.90 & -0.20 & 0.84 & 50.00 \\
\hline MP corrected & & -0.90 & 0.37 & & -0.11 & 0.91 & \\
\hline
\end{tabular}

Mikkelson \& Partch test; MP corrected, Mikkelson \& Partch test with the correction factor. Event date $=$ audit report date. A total of 185 observations are firms audited by a Big 4 company; 78 observations are firms audited by a non-Big 4 company

Significant at: $* 10 \%, * * 5 \%, * * * 1 \%$ 
services to the same client (Cameran et al. 2015). Therefore, it is easy to capture the propensity with which non-Big 4 auditors issue GCMs only when strictly necessary.

\section{Discussion}

In light of the results obtained, some implications emerge considering the main features of Italian listed firms, the accounting system, the market environment and corporate governance mechanisms. According to Nobes (1998, 2006), the Italian accounting system is situated in a type 2 culture, where the primary users of FSs are the government and creditors. This evidence adds to the debate on corporate governance mechanisms (Cremers and Nair 2005) and modifies the traditional agency problem, placing Italian firms among those with type II agency problems (Di Pietra et al. 2008). Thus, conflicts exist between majority and minority shareholders rather than between owners and managers due to the possibility of implementing actions that can be advantageous to controlling shareholders but cause damage to minority shareholders (Di Carlo 2014). These considerations are supported by our overall results.

Italian investors take into account audit reports, but their focus is mainly on the firm's financial conditions. Indeed, unqualified opinions with GCMs produce the main negative reaction, even though this category is generally considered "less serious" than GCMs attached to qualified opinions; however, as revealed by the average financial ratios, firms that have received unqualified opinions with a GCM display negative financial highlights in line with those that have received qualifications, showing a degree of financial distress that is very similar. Moreover, recurring GCMs produce an extended negative impact on stock prices because investors perceive the confirmation of financial distress without a natural switch from an unqualified to a qualified opinion. In addition, focusing on the latter aspect, we detect a strong reaction for "blacklisted companies", which are characterized by terrible financial conditions. Finally, the stronger negative reaction in the case of audit reports released by non-Big 4 companies reveals that investors have less confidence in Big 4 audit firms, fostering the "courage to choose" small and medium-sized audit firms.

In Italy, investor reactions are mainly due to minority shareholders, who do not trust the work of auditors. In a similar environment, there are few incentives for auditors to build their reputations based on audit quality since the processes of appointing and resigning are exclusively the result of the willpower of majority shareholders (Francis et al. 2003). Indeed, Cameran et al. (2010) draw a comprehensive picture of Big 4 audit firms in Italy, which are perceived as more successful, more internationally oriented and better known than their smaller counterparts; however, they are also considered more ambitious and arrogant and less effective and helpful. Ambition is considered detrimental to the quality of the auditor-client relationship. Moreover, Big 4 audit firms are perceived as more business oriented than small auditors.

The role of minority investors in determining abnormal returns is due to the ownership structure of Italian listed companies. More specifically, Italian listed firms are characterized by a quasi-systematic family concentrated ownership, and this frame is confirmed for the firms included in our sample. This results in a lower percentage of floating shares (approximately $30 \%$ of outstanding shares), which are traded 
only by minority shareholders (personally or through share trading services provided by institutional investors). This implies that the remaining $70 \%$ of outstanding shares (on average) are permanently in the hands of the family controlling shareholder; more importantly, these shares are not traded since the initial public offering launched at the time of listing entrance. In Italy, the minimum percentage of floating shares to be listed on the Milan Stock Exchange is quite lower (25\%); therefore, to a large extent, the entrance on the stock market is realized exclusively to raise funds and to increase brand value domestically and worldwide. In our view, this aspect warrants more attention from academics because the same results in studies such as this research are driven by totally different variables and could lead to different conclusions. Since the auditor is appointed by the controlling shareholder and the controlling shareholder has no or few shares traded on the stock market, adverse reactions to GCMs are largely due to minority shareholders, providing an empirical demonstration of the theoretical type II agency problem. At the same time, it cannot be neglected that the investment or disinvestment decisions of minority shareholders rely on the overall financial condition of the firm. Thus, in the absence of other confounding events, the detection of abnormal returns in response to a GCM is important for exploring and explaining how minority investors act in response to small market equity, characterized by the strong ownership concentration in Italy.

Reviewing all of this evidence, we see that further implications emerge. The primary objective to be achieved is an improvement in audit quality, especially, as in this case, in regard to GC issues.

From the regulatory perspective, it is important to underline that "revised" ISA No. 700 ("forming an opinion and reporting on financial statements"), in force since December 15, 2016, has modified the previous structure of the audit report, requiring more details and an explanatory paragraph containing any doubts about the fulfilment of the GC assumption. Under the revised" ISA 570, this paragraph is called "material uncertainty related to going concern", and it is required when there is material uncertainty but the GC disclosures are adequate. Differently, the previous ISA 570 included this section among the emphasis of matter paragraphs. Thus, currently, a "GC paragraph" could be seen as "quasi-mandatory" in the audit report. These regulatory updates are the first step towards improving audit procedures. At this point, the question is related to future investors' reaction to $\mathrm{GC}$ issue enforcement. The results obtained suggest that this introduction will be relevant for investors, but it would be interesting to verify how and in which direction stock market anomalies will result.

However, other considerations regarding the proper "categorization" of GCMs adopted by auditors arise. In Italy, the predominance of GCMs is represented by those attached to unqualified opinions, which do not properly reflect the adverse financial performance of the audited firm. Even if we can take for granted the correct behaviour of auditors during audit procedures, regulators can implement other legislative updates finalized at the issuance of fairer opinions. An example in this sense could be an accurate review of the materiality thresholds calculated during the audit planning (ISA 320 "materiality in planning and performing an audit") and Chong (2015) expresses the need for a common definition of materiality, especially in a litigious society such as contemporary society. From a different perspective, Audsabumrungrat et al. (2016) found that "audit managers make less appropriate materiality planning judgments 
with structured guidance than with unstructured guidance, and that this detrimental influence of structured materiality guidance is reduced when they are required to justify their materiality judgments". Importantly, their findings are based on a study conducted on Big 4 firms in Thailand, a country that has a market structure and corporate governance mechanisms similar to those in Italy (see Connelly et al. 2012). Finally, we must take into consideration our results on Big 4 and non-Big 4 companies, which show greater investor concerns over opinions issued by non-Big 4 auditors. The final consideration concerns the time span covered in this study compared with that of Ianniello and Galloppo (2015). More specifically, the time span used by Ianniello and Galloppo is stucked in the middle of the important regulatory amendment that occurred in 2009. This leads us to make three important remarks. First, they analysed 2 years (2007 and 2008) in which a GCM was not a relevant information for investors, and the remaining 2 years (2009 and 2010) had the new amendment. This could affect the reliability of their conclusions. Second, we analysed seven "homogenous" years (2009-2015), while they analysed only 4 years (not homogenous in pairs as explained). Third, our work represents an advance and uses a weighted stock index that replaces the FTSE MIB; this index has the advantage of considering the characteristics of the firms included in the sample in a fairer manner. Thus, it is plausible to support that our results have higher reliability in depicting the abnormal reactions of Italian investors to GCMs in light of the larger sample investigated.

\section{Final remarks and implications for future research}

An effective contribution to the existing literature on stock market reactions to financial reporting events lies in the reliability of the event date individuated and its capacity to largely determine abnormal returns. In light of these considerations, the Italian auditing and accounting legal settings were preliminarily reviewed to verify whether the audit report date can be considered a determinant and prevalent in causing stock market abnormal returns.

In relation to the empirical evidence obtained, we confirmed the first and basic hypothesis: GCMs have, on average, a negative impact on stock returns, mostly around the event date and immediately thereafter. On the other hand, the findings related to the second hypothesis, regarding the impact of unqualified opinions with GCMs, which was confirmed, partially contradict the evidence of Ianniello and Galloppo (2015). Indeed, reversing their results, this category generates significant negative abnormal returns.

Most likely, the CONSOB regulatory amendment in 2009, which requires an immediate communication of unqualified opinions with GCMs to the market, provides an effective explanation of this reversal. Our results show that investors have been able to capture this regulatory change.

Analysing the different impacts of first-time and recurring GCMs (H3), we obtain results that are in line with the international perspective. In fact, in the case of first-time GCMs, a negative reaction is detected especially around the event date and in the days immediately thereafter, confirming the value relevance in the short term of a first-time GCM. However, referring to recurring GCMs, the negative impact is confirmed and is even stronger, leading 
us to reject the third hypothesis. This could mean that in Italy, minority shareholders are much more concerned over the persistence of a GCM over time than elsewhere.

Notably, a certain sensitivity of the results to the tests that we used can be observed. Clearly, this implies that results may not always lead to univocal interpretations. To increase the robustness of results, it would be appropriate to specify a furtherly accurate model and to relax the assumption of constant volatility of ARs implied in all the tests considered (Castellano and Scaccia 2012).

In conclusion, to avoid further deterioration in the investor response and a systematic negative reaction to GCMs, it could be important to improve investors' knowledge of the issue, starting with an improvement in the materiality thresholds used in audit procedures. Future studies could further investigate the correspondence between the audit opinion and the client's performance to provide the final sign with regard to the necessity of regulatory improvements in this direction.

Funding Open access funding provided by Università degli Studi di Roma Tor Vergata within the CRUICARE Agreement.

Open Access This article is licensed under a Creative Commons Attribution 4.0 International License, which permits use, sharing, adaptation, distribution and reproduction in any medium or format, as long as you give appropriate credit to the original author(s) and the source, provide a link to the Creative Commons licence, and indicate if changes were made. The images or other third party material in this article are included in the article's Creative Commons licence, unless indicated otherwise in a credit line to the material. If material is not included in the article's Creative Commons licence and your intended use is not permitted by statutory regulation or exceeds the permitted use, you will need to obtain permission directly from the copyright holder. To view a copy of this licence, visit http://creativecommons.org/licen ses/by/4.0/.

\section{Appendices}

\section{Appendix 1}

See Table 9. 


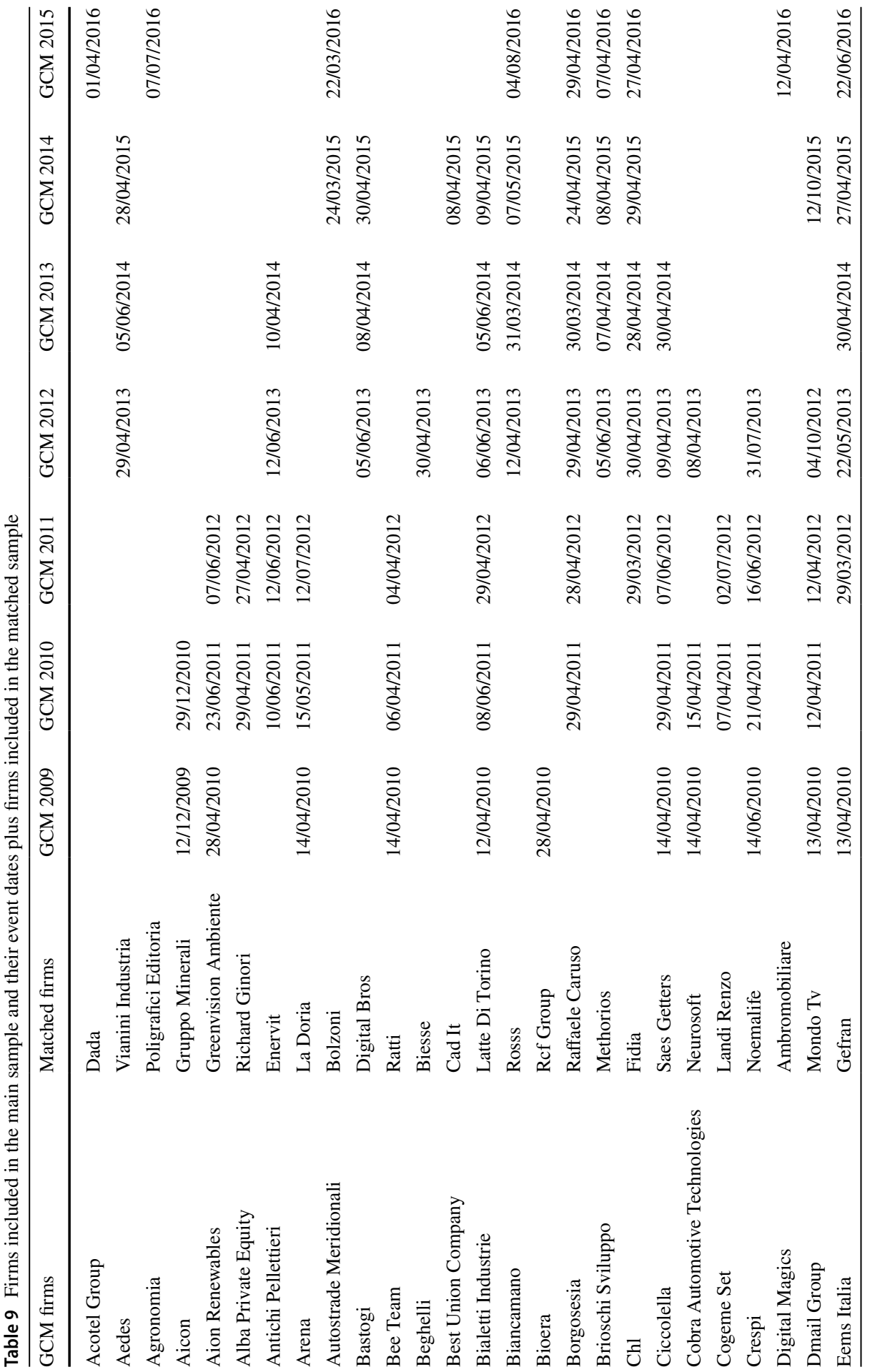




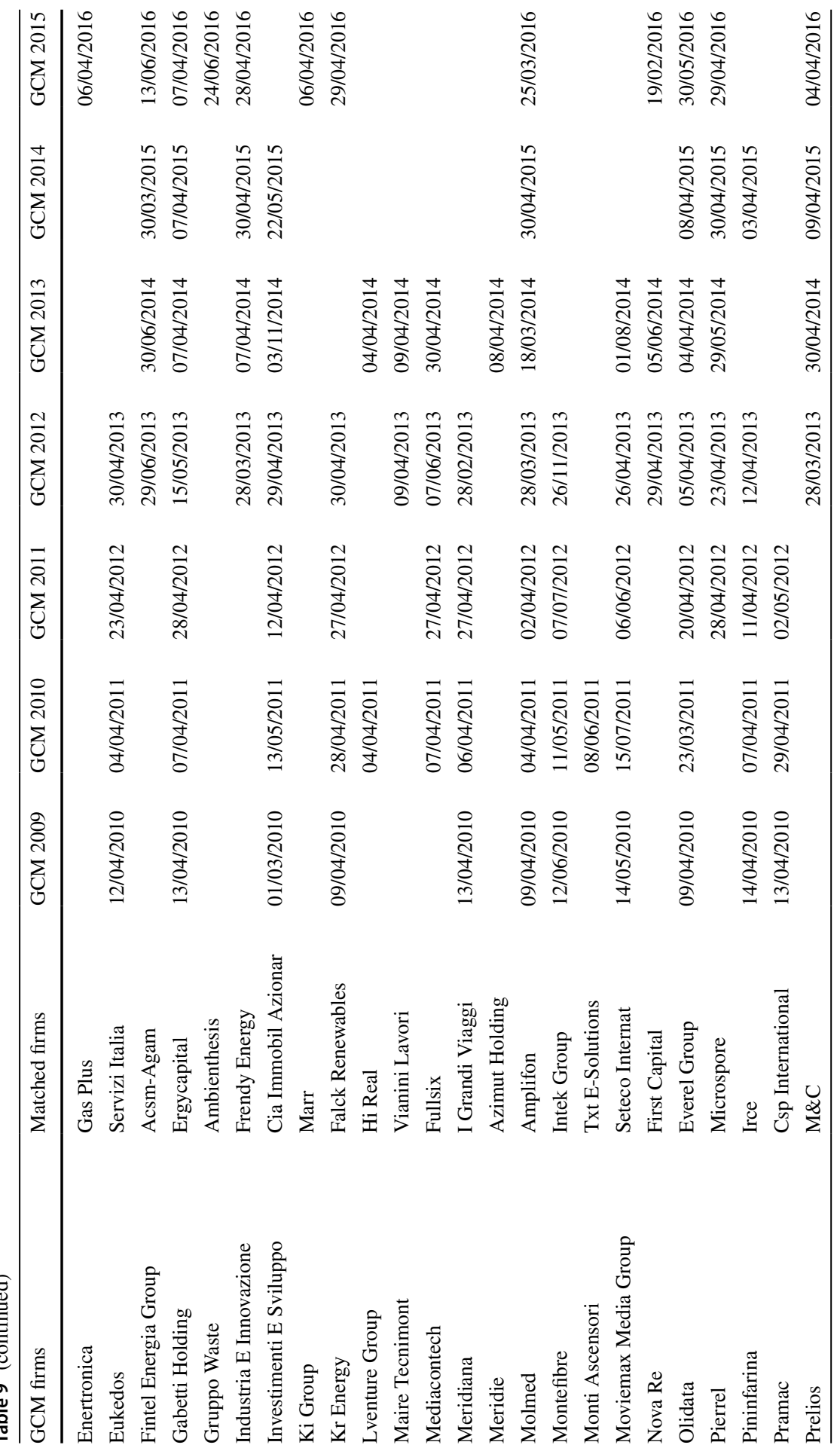




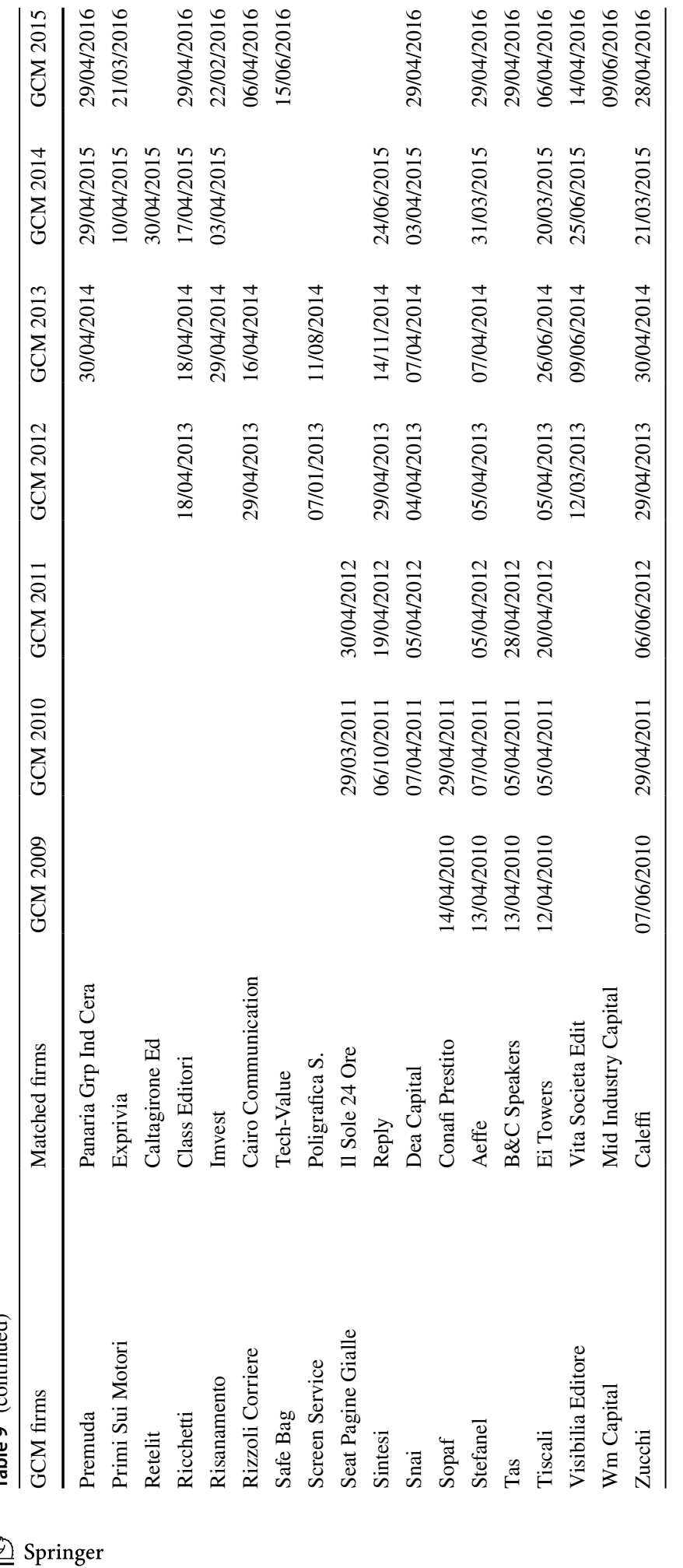




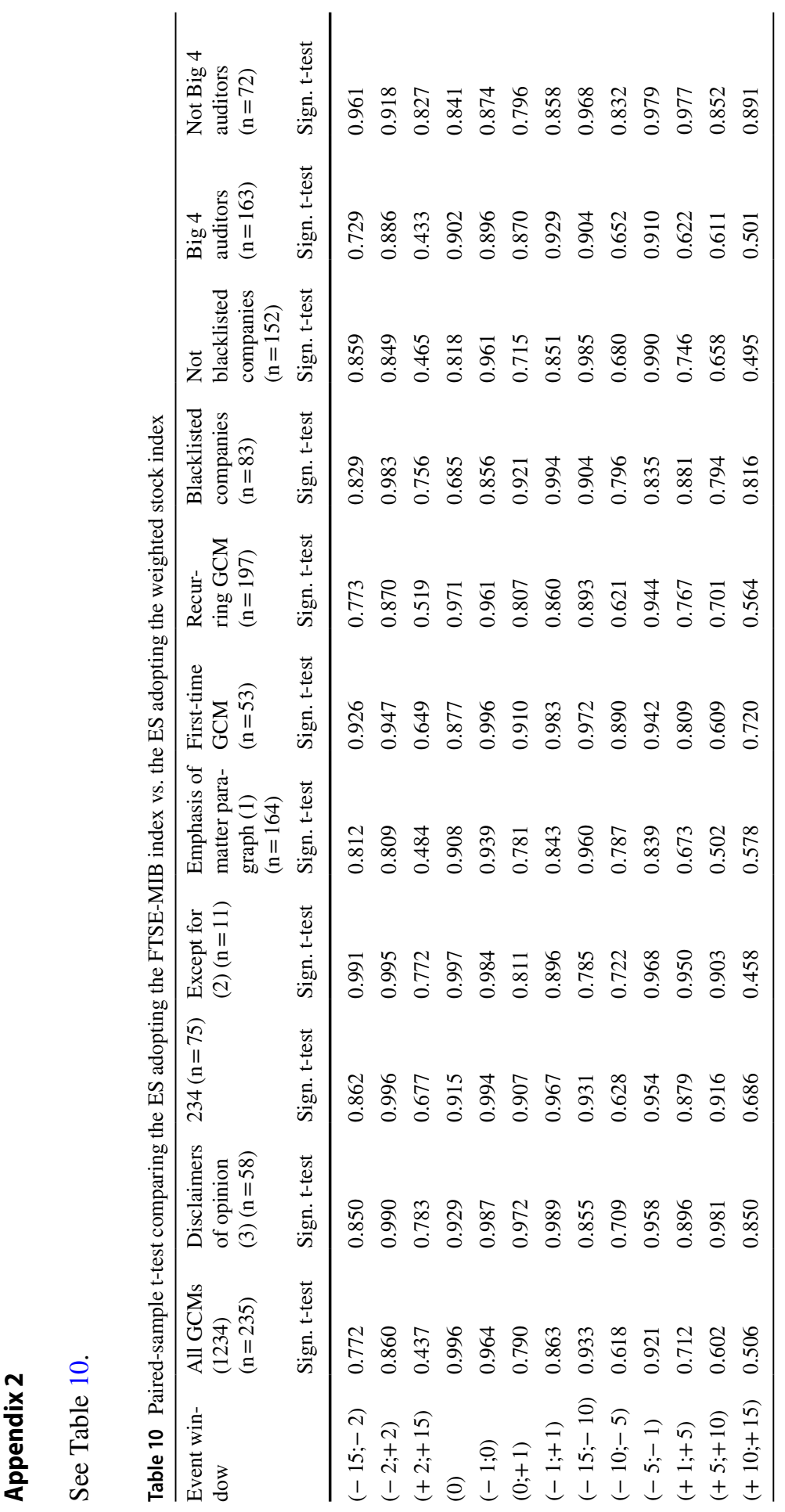




\section{References}

Achim, S., Bota-Avram, C., Moldovan, R., \& Moldovan, C. (2010). Going concern: A challenge for auditors and managers in the context of current economic crisis. Journal of International Management Studies, 10(3), 34-42.

Alderman, C. W. (1977). The role of uncertainty qualifications: Evidence to support the tentative conclusions of the Cohen Commission. Journal of Accountancy, 144(5), 97-100.

Allegrini, M., \& Greco, G. (2013). Corporate boards, audit committees and voluntary disclosure: evidence from Italian listed companies. Journal of Management and Governance, 17(1), 187-216.

Al-Thuneibat, A. A., Khamees, B. A., \& Al-Fayoumi, N. A. (2008). The effect of qualified auditors' opinions on share prices: evidence from Jordan. Managerial Auditing Journal, 23(1), 84-101.

Amin, K., Krishnan, J., \& Yang, J. S. (2014). Going concern opinion and cost of equity. Auditing: A Journal of Practice \& Theory, 33(4), 1-39.

Audsabumrungrat, J., Pornupatham, S., \& Tan, H. T. (2016). Joint impact of materiality guidance and justification requirement on auditors' planning materiality. Behavioral Research in Accounting, 28(2), 17-27.

Baskin, E. F. (1972). The communicative effectiveness of consistency exceptions. The Accounting Review, 47(1), 38-51.

Bessell, M., Anandarajan, A., \& Umar, A. (2003). Information content, audit reports and going-concern: An Australian study. Accounting \& Finance, 43(3), 261-282.

Blay, A. D., \& Geiger, M. A. (2001). Market expectations for first-time going-concern recipients. Journal of Accounting, Auditing \& Finance, 16, 209-226.

Blay, A. D., Geiger, M. A., \& North, D. S. (2011). The auditor's going-concern opinion as a communication of risk. Auditing: A Journal of Practice \& Theory, 30(2), 77-102.

Blay, A. D., Moon, J. R., \& Paterson, J. S. (2016). There's no place like home: the influence of homestate going-concern reporting rates on going-concern opinion propensity and accuracy. Auditing: A Journal of Practice \& Theory, 35(2), 23-51.

Boehmer, E., Musumeci, J., \& Poulsen, A. (1991). Event-study methodology under conditions of eventinduced variance. Journal of Financial Economics, 30(2), 253-272.

Brunelli, S. (2018). Audit reporting for going concern uncertainty-Global trends and the case study of Italy. Berlin: Springer.

Cameran, M., Francis, J. R., Marra, A., \& Pettinicchio, A. (2015). Are there adverse consequences of mandatory auditor rotation? Evidence from the Italian experience. Auditing: A Journal of Practice \& Theory, 34(1), 1-24.

Cameran, M., Gabbioneta, C., Moizer, P., \& Pettinicchio, A. (2010). What do client-firms think of their auditors? Evidence from the Italian Market. Corporate Reputational Review, 12(4), 316-326.

Campbell, J. Y., Lo, A. W., \& MacKinlay, A. C. (Eds.). (1997). The econometrics of financial markets. Princeton, NJ: Princeton University Press.

Carson, E., Fargher, N. L., Geriger, M. A., Lennox, C. S., Raghunandan, K., \& Willekens, M. (2013). Audit reporting for going-concern uncertainty: A research synthesis. Auditing: A Journal of Practice \& Theory, 32(Suppl. 1), 353-384.

Castellano, R., \& Scaccia, L. (2012). CDS and rating announcements: changing signaling during the crisis. Review of Managerial Science, 6(3), 239-264.

Chen, K. C. W., \& Church, B. K. (1996). Going-concern opinions and the market's reaction to bankruptcy filings. The Accounting Review, 71, 117-128.

Chen, P. F., He, S., Ma, Z., \& Stice, D. (2016). The information role of audit opinions in debt contracting. Journal of Accounting and Economics, 61(1), 121-144.

Chen, C. J. P., Su, X., \& Zhao, R. (2000). An emerging market's reaction to initial modified audit opinions: evidence from the Shanghai stock exchange. Contemporary Accounting Research, 17(3), 429-455.

Chong, H. G. (2015). A review on the evolution of the definitions of materiality. International Journal of Economics and Accounting, 6(1), 15-32.

Chow, C. W., \& Rice, S. J. (1982). Qualified audit opinions and share prices-an investigation. Auditing: A Journal of Practice \& Theory, 1(2), 35-53.

Citron, D. B., Taffler, R. J., \& Uang, J. Y. (2008). Delays in reporting price-sensitive information: The case of going-concern. Journal of Accounting and Public Policy, 17, 19-37. 
Connelly, J. T., Limpaphayom, P., \& Nagarajan, N. J. (2012). Form versus substance: the effect of ownership structure and corporate governance on firm value in Thailand. Journal of Banking \& Finance, 36(6), 1722-1743.

Craswell, A. T. (1985). Studies of the information content of qualified audit reports. Journal of Business Finance \& Accounting, 12(1), 93-115.

Cremers, M., \& Nair, V. (2005). Governance mechanisms and equity prices. The Journal of Finance, 60(6), 2859-2894.

Czerney, K., Shmidt, J. J., \& Thompson, A. N. (2019). Do investors respond to explanatory language included in unqualified audit reports? Contemporary Accounting Research, 36(1), 198-229.

Davis, R. (1982). An empirical evaluation of auditors subject-to opinions. Auditing: A Journal of Practice \& Theory, 2(1), 13-32.

DeFond, M. L., \& Francis, J. J. R. (2005). Audit research after Sarbanes-Oxley. Auditing: A Journal of Practice \& Theory: Supplement, 24(1), 5-30. https://doi.org/10.2308/aud.2005.24.s-1.5.

DeFond, M. L., Wong, T. J., \& Li, S. (2000). The impact of improved auditor independence on audit market concentration in China. Journal of Accounting and Economics, 28(3), 269-305.

DeFond, M. L., \& Zhang, J. (2014). A review of archival auditing research. Journal of Accounting and Economics, 58, 275-326.

Di Carlo, E. (2014). Pyramids and the separation between direction and control of non-financial Italian family companies. Journal of Management and Governance, 18(3), 835-872.

Di Pietra, R., Grambovas, C., Raonic, V., \& Riccaboni, A. (2008). The effects of board size and 'busy' directors on the market value of Italian companies. Journal of Management and Governance, 12(1), 73-91.

Dopuch, N., Hothausen, R., \& Leftwich, R. (1986). Abnormal stock returns associated with media disclosure of subject to qualified audit opinions. Journal of Accounting and Economics, 8(2), 93-117.

Elliott, J. (1982). "Subject to"' audit opinions and abnormal security returns: Outcomes and ambiguities. Journal of Accounting Research, 20, 617-638.

Fama, E. F. (1991). Efficient capital markets: II. Journal of Finance, 46(5), 1575-1617.

Firth, M. (1978). Qualified audit reports: their impact on investment decisions. The Accounting Review, $53(3), 642-650$

Fleak, S. K., \& Wilson, E. R. (1994). The incremental information content of the going-concern audit opinion. Journal of Accounting, Auditing \& Finance, 9, 149-166.

Foster, B. P., Ward, T. J., \& Woodroof, J. (1998). An analysis of the usefulness of debt defaults and going concern opinions in bankruptcy risk assessment. Journal of Accounting, Auditing and Finance, 13(3), 351-371.

Francis, J. R., Khurana, I. K., \& Pereira, R. (2003). The role of accounting and auditing in corporate governance and the development of financial markets around the world. Asia Pacific Journal of Accounting and Economics, 10(1), 1-30.

Francis, J., \& Yu, M. D. (2009). Big 4 office size and audit quality. The Accounting Review, 84(5), $1521-1552$

Geiger, M. A., \& Kumas, A. (2018). Anticipation and reaction to going-concern modified audit opinions by sophisticated investors. International Journal of Auditing, 22(3), 522-535.

Geiger, M. A., \& Rama, D. V. (2006). Audit firm size and going-concern reporting accuracy. Accounting Horizons, 20, 1-17.

Gold, A., Geiger, M., \& Wallage, P. (2019). A synthesis of research on auditor reporting on going-concern uncertainty: An update and extension. Breukelen: Foundation for Auditing Research.

Gray, G. L., Turner, J. L., Coram, P. J., \& Mock, T. J. (2011). Perceptions and misperceptions regarding the unqualified auditor's report by financial statement preparers, users, and auditors. Accounting Horizons, 25, 659-684.

Herbohn, K., Ragunathan, V., \& Garsden, R. (2007). The horse has bolted: Revisiting the market reaction to going concern modifications of audit reports. Accounting \& Finance, 47(3), 473-493.

Hitchner, J. R. (2017). Financial valuation: Applications and models, Fourth Edition + Website, Fourth Edition. New York: Wiley.

Hsu, J., Young, W., \& Chu, C. H. (2011). Price behavior of qualified companies around the audit report and report announcement days: The case of Taiwan. Journal of International Financial Management \& Accounting, 22(2), 114-130.

Hunt, A. K., \& Lulseged, A. (2007). Client importance and non-Big 5 auditors' reporting decisions. Journal of Accounting and Public Policy, 26, 212-248. 
Ianniello, G., \& Galloppo, G. (2015). Stock market reaction to auditor opinions-Italian evidence. Managerial Auditing Journal, 30(6), 610-632.

Jones, F. L. (1996). The information content of the auditor's going-concern evaluation. Journal of Accounting and Public Policy, 15, 1-27.

Kaplan, S. E., Mowchan, M, \& Weisbrod, E. (2014). Does institutional investor behavior influence the market reaction to going concern audit reports? https://doi.org/10.2139/ssrn.2433626.

Karjalainen, J. (2011). Audit quality and the cost of debt capital for private firms: Evidence from Finland. International Journal of Auditing, 15, 88-108.

Kausar, A., Taffler, R. J., \& Tan, C. E. L. (2017). Legal regimes and investor response to the auditor's going-concern opinion. Journal of Accounting, Auditing \& Finance, 32(1), 40-72.

Kolari, J. W., \& Pynnönen, S. (2010). Event study testing with cross-sectional correlation of abnormal returns. Review of Financial Studies, 23(11), 3996-4025.

Krishnan, J., Krishnan, J., \& Stephens, R. (1996). The simultaneous relation between auditor switching and audit opinion: an empirical analysis. Accounting \& Business Research, 26(3), 224-236.

LaSalle, R., \& Anandarajan, A. (1996). Auditors' views on the type of audit report issued to entities with going concern uncertainties. Accounting Horizons, 10(2), 51-72.

Lennox, C. (1999). Are large auditors more accurate than small auditors? Accounting and Business Research, 29, 217-227.

Loudder, M. L., Khurana, I. K., Sawyers, R. B., Cordery, C., Johnson, C., Lowe, J., et al. (1992). The information content of audit qualifications. Auditing: A Journal of Practice \& Theory, 11, 69-83.

Menon, K., \& Williams, D. D. (2010). Investor reaction to going concern audit reports. The Accounting Review, 85, 2075-2105.

Mentz, M., \& Schiereck, D. (2008). Cross-border mergers and the cross-border effect: The case of the automotive supply industry. Review of Managerial Science, 2(3), 199-218.

Mikkelson, W. H., \& Partch, M. M. (1988). Withdrawn security offerings. The Journal of Financial and Quantitative Analysis, 23(2), 119-133.

Mock, T. J., Bédard, J., Coram, P. J., \& Davis, S. M. (2013). The audit reporting model: Current research synthesis and implications. Auditing: A Journal of Practice \& Theory, 32(1), 323-351.

Nobes, C. (1998). Towards a general model of the reasons for international differences in financial reporting. Abacus, 34(2), 162-187.

Nobes, C. (2006). The survival of international differences under IFRS: Towards a research agenda. Accounting \& Business Research, 36(3), 233-245.

Nobes, C., \& Parker, R. (Eds.). (2016). Comparative international accounting (13th ed.). Edinburgh: Pearson.

Pei, D., \& Hamill, P. A. (2013). Do modified audit opinions for Shanghai listed firms convey heterogeneous information? Journal of International Accounting, Auditing and Taxation, 22(1), 1-11.

Porter, B., hÒgartaigh, C. Ò., \& Baskerville, R. (2009). Report on research conducted in the United Kingdom and New Zealand in 2008 investigating the audit expectation-performance gap and users' understanding of, and desired improvements to, the auditor's report. http://web.ifac.org/download/ Porter_et_al_Final_Report_Combined.pdf.

Pucheta-Martínez, M. C., Martínez, A. V., \& Benau, M. A. G. (2004). Reactions of the Spanish capital market to qualified audit reports. Eur. The Accounting Review, 13(4), 689-711.

Solomon, D. (2017). The voice: the minority shareholder's perspective. Nevada Law Journal, 17, 739.

Soltani, B. (2000). Some empirical evidence to support the relationship between audit reports and stock prices-The french case. International Journal of Auditing, 4(3), 269-291.

Taffler, R. J., Lu, J., \& Kausar, A. (2004). In denial? Stock market underreaction to going-concern audit report disclosures. Journal of Accounting \& Economics, 38, 263-296.

Vanstraelen, A. (2003). Going-concern opinions, auditor switching, and the self-fulfilling prophecy effect examined in the regulatory context of Belgium. Journal of Accounting, Auditing \& Finance, 18(2), $231-256$.

Publisher's Note Springer Nature remains neutral with regard to jurisdictional claims in published maps and institutional affiliations. 
Sandro Brunelli is aggregate Professor of financial reporting at the University of Rome Tor Vergata and teaching contract professor of Financial and Managerial Accounting at ESCP Business School Turin Campus. His research activity covers mainly the areas of accounting, auditing, accountability and governance issues in both private and public sectors.

Chiara Carlino has got a Ph.D. in Business Management and Accounting at the University of Rome Tor Vergata. She works has a business analyst for Leo Pharma Inc. in Copenhagen (Denmark). Her research activity covers the areas of financial accounting and external auditing in private sector.

Rosella Castellano is full Professor of Mathematical Methods in Economics, Actuarial and Financial Sciences at the University of Rome Unitelma-Sapienza and non-executive board member of Monte dei Paschi di Siena Bank. She directed the Master in Economics and Anti-Money Laundering at the University of Macerata and was Officer at the Presidency of the Council of Ministers. Her research activity covers mainly quantitative finance issues.

Alessandro Giosi is Associate Professor of Business Administration at the LUMSA University of Rome and the academic director of the bachelor in communication science, marketing and digital media. He is also teaching contract professor of Business Administration at the University of Rome Tor Vergata. His research activity covers mainly the areas of accounting, accountability and governance issues in both private and public sectors.

\section{Affiliations}

\section{Sandro Brunelli ${ }^{1}$ (1) $\cdot$ Chiara Carlino $^{1} \cdot$ Rosella Castellano $^{2} \cdot$ Alessandro Giosi $^{3}$}

Chiara Carlino

chiara.carlino@uniroma2.it

Rosella Castellano

rosella.castellano@unitelma.it

Alessandro Giosi

a.giosi@lumsa.it

1 Department of Management and Law, University of Rome "Tor Vergata", 00133 Rome, Italy

2 Department of Law and Economics, University of Rome "Unitelma-Sapienza", 00161 Rome, Italy

3 Department of Human Science, LUMSA University, 00193 Rome, Italy 